\title{
Review \\ Microsatellite Instability Analysis (MSA) for Bladder Cancer: Past History and Future Directions
}

\author{
Chulso Moon ${ }^{1,2,3, *}$, Maxie Gordon ${ }^{2,3}$, David Moon ${ }^{2}$ and Thomas Reynolds 4 \\ 1 Department of Otolaryngology-Head and Neck Surgery, The Johns Hopkins Medical Institution, \\ Cancer Research Building II, 5M3, 1550 Orleans Street, Baltimore, MD 21205, USA \\ 2 HJM Cancer Research Foundation Corporation, 10606 Candlewick Road, Lutherville, MD 21093, USA; \\ maxiegordon@bellsouth.net (M.G.); david_moon@alumni.brown.edu (D.M.) \\ 3 BCD Innovations USA, 10606 Candlewick Road, Lutherville, MD 21093, USA \\ 4 NEXT Bio-Research Services, LLC, 11601 Ironbridge Road, Suite 101, Chester, VA 23831, USA; \\ treynolds@nextmolecular.com \\ * Correspondence: csmoon6@gmail.com; Tel.: +1-(443)-370-5056
}

check for updates

Citation: Moon, C.; Gordon, M.; Moon, D.; Reynolds, T. Microsatellite Instability Analysis (MSA) for Bladder Cancer: Past History and Future Directions. Int. J. Mol. Sci. 2021, 22, 12864. https://doi.org/ 10.3390/ijms222312864

Academic Editor: Wilhelm K. Aicher

Received: 3 October 2021

Accepted: 19 November 2021

Published: 28 November 2021

Publisher's Note: MDPI stays neutral with regard to jurisdictional claims in published maps and institutional affiliations.

Copyright: (c) 2021 by the authors. Licensee MDPI, Basel, Switzerland. This article is an open access article distributed under the terms and conditions of the Creative Commons Attribution (CC BY) license (https:/ / creativecommons.org/licenses/by/ $4.0 /)$.

\begin{abstract}
Microsatellite instability (MSI), the spontaneous loss or gain of nucleotides from repetitive DNA tracts, is a diagnostic phenotype for gastrointestinal, endometrial, colorectal, and bladder cancers; yet a landscape of instability events across a wider variety of cancer types is beginning to be discovered. The epigenetic inactivation of the MLH1 gene is often associated with sporadic MSI cancers. Recent next-generation sequencing (NGS)-based analyses have comprehensively characterized MSI-positive (MSI+) cancers, and several approaches to the detection of the MSI phenotype of tumors using NGS have been developed. Bladder cancer (here we refer to transitional carcinoma of the bladder) is a major cause of morbidity and mortality in the Western world. Cystoscopy, a gold standard for the detection of bladder cancer, is invasive and sometimes carries unwanted complications, while its cost is relatively high. Urine cytology is of limited value due to its low sensitivity, particularly to low-grade tumors. Therefore, over the last two decades, several new "molecular assays" for the diagnosis of urothelial cancer have been developed. Here, we provide an update on the development of a microsatellite instability assay (MSA) and the development of MSA associated with bladder cancers, focusing on findings obtained from urine analysis from bladder cancer patients as compared with individuals without bladder cancer. In our review, based on over 18 publications with approximately 900 sample cohorts, we provide the sensitivity ( $87 \%$ to $90 \%)$ and specificity ( $94 \%$ to $98 \%$ ) of MSA. We also provide a comparative analysis between MSA and other assays, as well as discussing the details of four different FDA-approved assays. We conclude that MSA is a potentially powerful test for bladder cancer detection and may improve the quality of life of bladder cancer patients.
\end{abstract}

Keywords: bladder cancer; microsatellite; molecular diagnostics

\section{Introduction}

Microsatellite instability (MSI) is a molecular tumor phenotype resulting from genomic hypermutability and is initially described as variations in the length of microsatellite sequences in the entire genomic structure. As part of the familiar colon cancer syndrome, MSI is most commonly observed among Lynch syndrome patients [1-3]. However, since its initial discovery, MSI has been acknowledged as a generalized phenomenon in a wide spectrum of sporadic cancers [4-8], and the underlying mechanisms for these cases of sporadic cancers seem to be based on epigenetic mechanisms, namely the methylation of MLH1. Probably the most deleterious outcome of MSI, in either inherited or sporadic sold tumors, is the frameshift mutations in tumor-associated genes, which can be accumulated over a long period of time. This process plays a crucial role in the various stages of human carcinogenesis. MSI detection is currently achieved by examining PCR products from a 
few important microsatellite markers (MSI-PCR) $[9,10]$. Recently, several groups have developed methods to analyze MSI using massively parallel DNA-sequencing technologies [11-16]. This new approach is not only based on a large number of samples but is also designed to offer robust quality and quantitative precision that was not previously achievable using the PCR technique. Notably, Cancer Genome Atlas (TCGA) made it possible to predict MSI status regardless of cancer through information from tumor exomes sequencing. This approach resulted in a more comprehensive understanding of genomewide MSI [13]. Likewise, next-generation sequencing (NGS) also become a useful tool in examining MSI-positive carcinogenesis, in addition to discovering valuable biomarkers and novel therapeutic targets [15]. Here, we review the latest progresses in the investigation of MSI+ (MSI positive) carcinogenesis [17-35]. Bladder cancer (here we refer to transitional carcinoma of the bladder) has become one of the major causes of cancer-specific morbidity and mortality in various parts of the world [36]. Our understanding of its etiology, the molecular characteristics associated with its progression, and management guidelines render bladder cancer an ideal candidate for screening [36-39]. The diagnosis and follow-up of bladder cancer is still very difficult due to the lack of cancer-specific symptoms and therefore become a challenge for the medical community, not only for urologists but also for primary care physicians $[36,39]$. Cystoscopy, which has been used as a gold standard for the detection of bladder cancer, is naturally invasive, with frequent complications, while its cost is relatively high [39]. Urine cytology provides only limited diagnostic value due to its low sensitivity, particularly to low-grade tumors [36,39]. Due to urgent need, new qualitative and quantitative molecular tests designed to identify cellular and molecular changes exclusively associated with bladder cancer have been explored [38,39]. Therefore, over the last three decades, several new "molecular tests" for the diagnosis of urothelial cancer have been developed. In fact, studies of several molecular assays combined with traditional screening methods have demonstrated promising results [39]. $\mathrm{LOH}$ is typically identified by comparing the DNA isolated from tumors to normal DNA, such as that isolated from blood [7-9]. This LOH can be detected using a method known as microsatellite instability analysis (MSA).

Here, we review the discovery and evolution of MSI in cancer biology, as well as the development of different techniques for detecting MSI [4,6]. Next, we focus on the use of MSA for bladder cancer detection, focusing on its initial and later clinical development. We also discuss the use of MSA for the early detection of bladder cancer and its role as a tool in the surveillance of recurrent bladder cancer. Additionally, we discuss four different technical guidance approaches in the conclusion section.

The intention of this report is to provide a comprehensive narrative review and not a meta-analysis. We use the following review criterion: a literature review based on searching PubMed for original articles published between 1968 and 2021, using the search terms "bladder cancer", "microsatellite instability" "urine biomarker", "recurrent bladder cancer surveillance", "LOH for bladder cancer detection", and "bladder cancer management". The search was limited to full-text articles written in the English language. Published reviews were used as additional sources of references.

\section{An Overview of MSI}

\subsection{Initial Discoveries and Clinical Applications}

Four pathways have been identified as causes of genomic instability for various cancer types, including gastrointestinal cancer [17-20]. First, chromosomal instability (CIN) phenotype, characterized by aneuploidy and multiple structural rearrangements in multiple loci of chromosomes, is found in the majority of solid tumors. Second, in initially discovered colon cancer, an accumulation of newly generated somatic mutations among oncogenes (K-ras) and tumor suppressor genes (APC and p53) can be a direct cause of genomic instability. Third, the accumulation of DNA demethylation can be a precursor to genomic instability among some subsets of gastrointestinal cancers [21,22]. Fourth, the MSI phenotype can result in multiple small insertions and deletions among repetitive 
sequences (microsatellites) and was reported in 10\% to $15 \%$ of sporadic colon cancers. Therefore, various tumors associated with Lynch syndrome (HNPCC) and certain patients populations with gastrointestinal and endometrial cancer are associated with the MSI pathway $[23,24]$. Tumors with MSI phenotypes can carry accumulated somatic mutations, which are caused by alterations in multiple simple repeated sequences (microsatellites).

In Figure 1, an example of CAG repeats (microsatellite) gains and losses due to DNA replication error and repair pathways correcting such mistakes is shown as a simple diagram [24]. A normal human genome contains numerous triple base repeats (such as the CAC repeats in Figure 1) and these repeats are prone to DNA replication errors due to DNA polymerase slippage, which can result in either the gain or loss of triplet repeat [23]. In normal cells, DNA mismatch repair (MMR) machinery guarantees $t$ genomic fidelity by recognizing, with the help of the MSH2/MSH6 enzymatic complex, DNA replication errors; the MLH1/PMS2/1 complex then repairs these DNA replication mistakes. However, in MSI tumor cells, the presence of a deficient MMR (dMMR) system results in the failure to repair DNA mismatches in microsatellites, resulting in the accumulation of mutations in different genomic codons [23,24]. In summary, when the DNA mismatch repair system (MMR mechanism) does not faithfully execute its work, DNA replication begins to cause accumulated DNA strand misalignment, which then becomes permanent new genetic material, leading to permanent genomic instability. The fact that serious defects in the replication fidelity of these unstable sequences can result in ubiquitous somatic mutations is one of the key insights supporting "the mutator phenotype for human carcinogenesis" [17,18].

CACA repeats are vulnerable to replication error

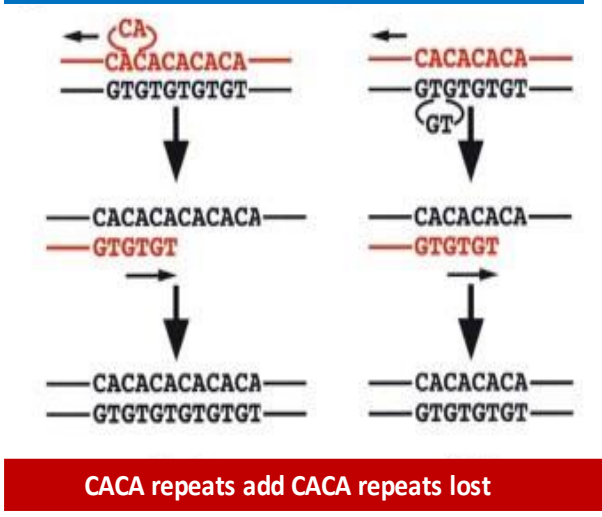

DNA mutation is successfully repaired, and mutated $A$ is removed

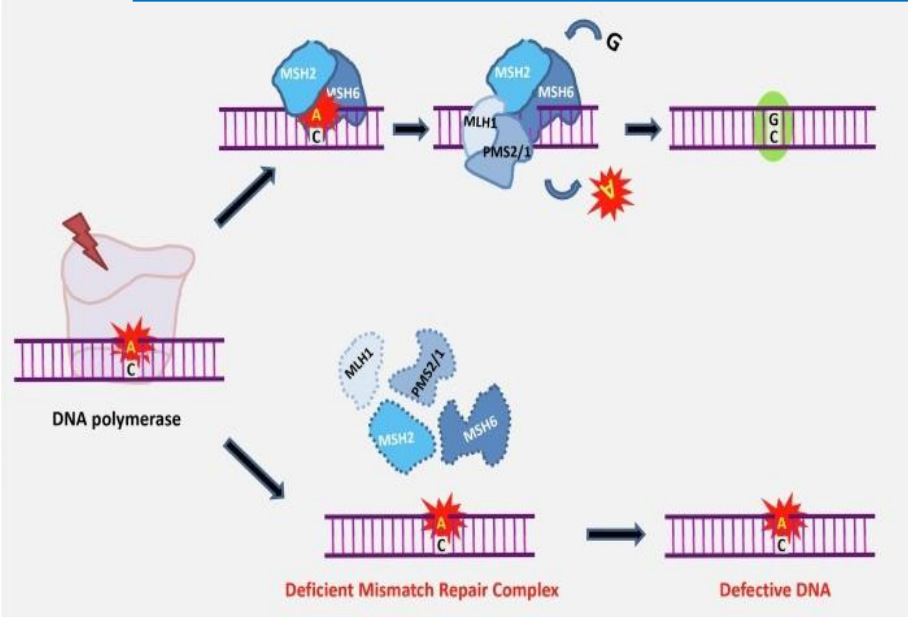

DNA mutations is NOT repaired, and mutated $A$ is NOT removed

Figure 1. Development of repeat base abnormalities and role of mismatch repair in maintaining genomic fidelity. In the left side of the figure, an example of CAG repeat (microsatellite) gains and losses during DNA replication is shown. In the right side of the figure, the role of the mismatch repair complex in preventing replication errors is described. In normal cells, the DNA mismatch repair (MMR) machinery guarantees genomic fidelity by recognizing (via MSH2/MSH6 complex) and repairing (via MLH1/PMS2/1 complex) genetic mismatches generated during DNA replication. When normal G/C base pairs are mutated into $\mathrm{A} / \mathrm{C}$ base pairs during DNA replication, the repair system recognizes the error (through MSH2/MSH6) and mutated A is then removed and replaced by correct C base via MLH1 and PMS1/2 machinery. Conversely, in MSI tumor cells, the presence of a deficient MMR (dMMR) system results in the failure to repair DNA mismatches in microsatellites, resulting in the accumulation of mutations in different genomic codons. So far, MLH1, MSH2, MSH6, and PMS2/1 have been found to be the main components of the MMR machinery. Modified from figure by Puliga E et al. [24]. 
Based on initial studies on Lynch syndrome, multiple studies of MSI for various forms of human carcinogenesis have resulted in three key conclusions. First, impairments in the mismatch repair (MMR) system $[23,24]$ can be caused by either the mutational deactivation of the enzymatic function or the DNA methylation-based silencing of several key genes in the MMR pathway [24]. Second, overall, MSI-positive (MSI+) cancers carry unique genetic, molecular, and clinical phenotypes, which can differentiate them from MSI-negative (MSI-) cancers. Third, MSI can cause multiple mutations, which can lead to the activation and deactivation of oncogenes and tumor suppressor genes, and a series of these processes then can become a pivotal force in driving human carcinogenesis.

Recent work suggests that MSI may be used as a predictor for immune-checkpointblockade therapy. Several clinical studies have shown better outcomes among patients with MSI-positive tumors as compared to negative groups when they are treated with inhibitors of programmed cell death 1 (PD-1). These observations can be explained by the ability of $\mathrm{T}$ lymphocyte to detect multiple peptides neoantigens produced by a variety of MSI-based DNA mutations $[25,26]$. While mutations resulting from MSI can also initiate multiple steps of oncogenesis, MSI signatures can be distinctive among different cancer types as different genomic loci can be unstable depending on the tumor type [11,28-34]. Moreover, depending on the tumor type, each MSI carries unique different prognostic meanings [29] with different frequencies [28]. Several parameters are used for MSI detection, and these parameters can change the accuracy for MSI detection among different cancer types as each cancer type differs according to the type of microsatellite markers. Several microsatellite panels have been proposed for the accurate detection of MSI, including the Bethesda/NCI panel, the gold standard microsatellite panel for MSI detection [28,35].

\subsection{Evolution of MSA Methods}

MSI detection methods have constantly changed through the pursuit of better accuracy and efficiency, which rely on the amplification of one or several microsatellite markers with PCR and the detection of MSI (Figure 2). MSI detection was first tested among colorectal cancer samples by using PCR on specific MSI markers with polyacrylamide gel electrophoresis and autoradiography [3]. Furthermore, a fingerprinting method based on arbitrarily primed PCR (AP-PCR) was combined with electrophoresis [2]. In some laboratories, MSI detection was performed with silver or ethidium bromide staining of polyacrylamide gel. These methods are laborious, costly, and time-consuming, often resulting in inconsistent accuracy. They have therefore been replaced by a newer approach, which is based on PCR with fluorescent primers and capillary electrophoresis using a DNA genetic analyzer. This new method has also been modified by the multiplexing of PCR to allow amplification of 2-5 microsatellite markers.

\subsection{Loss of Heterozygosity ( $\mathrm{LOH}$ ) in Bladder Cancer Patients}

Bladder cancer develops through several premalignant stages; the search for chromosomal markers that can serve as early neoplasia detection markers or predict recurrence has identified several genomic regions that contribute to neoplastic progression. Many studies have focused on the loss or inactivation of tumor suppressor genes (TSGs). TSGs can be inactivated by numerous mechanisms, including point mutation, loss of heterozygosity $(\mathrm{LOH})$, homozygous deletion, and hypermethylation. $\mathrm{LOH}$ has emerged as a major marker of bladder cancer tumor progression [27,34]. TSGs are one of the most common genetic changes in human cancers and $\mathrm{LOH}$ can play a vital role in inactivating these genes. Abnormalities involving p16 (chromosome 9p21) and p53 (17p13) are associated with superficial transitional cell carcinoma (TCC) and these two genes are among the two most frequently observed areas of $\mathrm{LOH}$ in bladder cancer. $\mathrm{LOH}$ at $9 \mathrm{p}$ has been shown to offer prognostic value in non-muscle-invasive bladder cancer [36], as well as 18q, 4p, 16, 20, and 21 [36]. $\mathrm{LOH}$ is typically identified by comparing the DNA isolated from tumors to normal DNA, isolated from blood. 

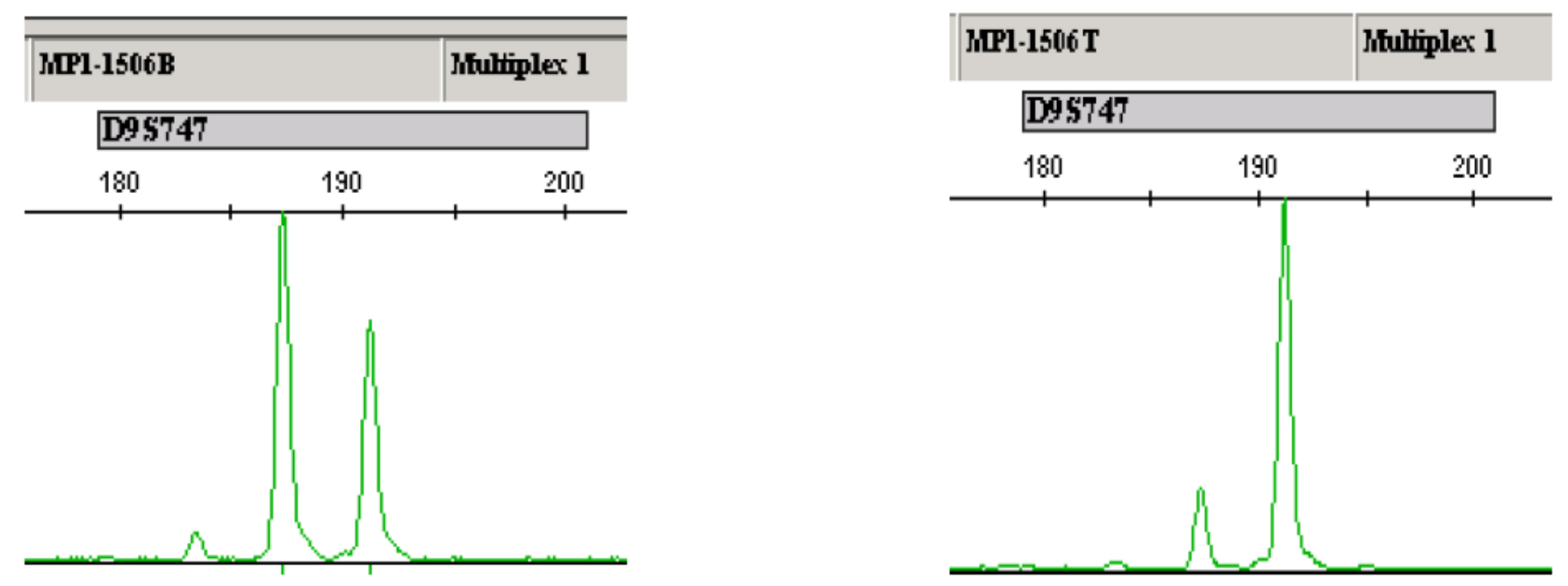

\section{Blood DNA}

\section{Urine DNA}

Figure 2. Example of MSA by genetic analyzer. In the upper panel, an MSI marker, M1506, is shown. In the left panel, a germ line MSI pattern is shown with two major peaks. In the right panel, both of the two peaks have been changed. These changes are detected by a series of algorithms in the ABI genetic analyzer.

\section{Use of Microsatellite Assay for Bladder Cancer Detection}

\subsection{Bladder Cancer Overview and Diagnostic Biomarkers}

The incidence and prevalence of transitional cell carcinoma of the bladder ('urothelial carcinoma'), the most frequently observed type of urinary bladder cancer in the Western world, has significantly increased in the past two decades, while its disease control in terms of mortality rate has not improved [37]. Additionally, its management cost per patient in the US has become the highest among any cancers. In the USA alone, by 2015 , the associated direct and indirect medical costs added up to $\$ 4$ billion per year [38]. The absence of bladder tumor-specific symptoms makes both the initial diagnosis and the follow-up of bladder cancer a significant burden not only for urologists but also the medical community in general. Cystoscopy, the gold standard for the detection of bladder cancer, is invasive and sometimes carries unwanted procedures related complications, while its cost is relatively high. Most recently, new technologies such fluorescence or narrow-band imaging-assisted cystoscopy, have emerged as potential tools. However, their invasive nature and added costs still prevent them from becoming standard practice. Overall, any measures for improved accuracy, simpler, and less expensive diagnostic tests are urgently needed for the improved management of bladder cancer [39-41]. For a long time, the cytology test from voided urine has been a dependably specific, noninvasive supplementary test to cystoscopy. However, it features two major limitations. First, while it offers a reasonably acceptable sensitivity for identifying high-grade urothelial cancer, its rate of detection for low-grade tumors ranges from only $4 \%$ to $31 \%$ [42]. Second, the accuracy of cytology is largely based upon the subjective readings of pathologists, which makes it difficult to provide a dependable, high-quality reading. Naturally, due to the urgent need, new qualitative and quantitative molecular tests designed to identify cellular and subcellular alterations exclusively associated with bladder cancer have been explored.

In fact, in the last two decades, several new "biochemical and molecular assays" for the diagnosis of urothelial cancer have been reported. What should we expect from these new tests? First, easier, better, faster, and cost-efficient ways of screening for bladder cancer 
have been regarded as the four gold standards for determining better methods for the surveillance of low-grade tumors with papillary features. Second, and at the same time, such noninvasive methods need to offer reasonably high sensitivity and specificity. Third, the goal of such tests needs to be aimed at decreasing the need for cystoscopies, thereby improving patient quality of life. Fourth, for high-grade disease, the improved sensitivity of markers can result in earlier identification of recurrent tumoral disease. As mentioned above, an ideal marker can be defined as a test that offers 'easier, better, faster, cost-efficient' cancer detection [43]. So far, several viable new urine markers for the diagnosis of bladder cancer have been reported. Many of them demonstrate superior sensitivity to that of standard urine cytology, and it is important to note that this improved diagnostic accuracy seems to be crucial in detecting low-to-moderate grade lesions, although none of them have been used as a standard diagnostic test in clinical management guidelines $[44,45]$. There are two different types of noninvasive bladder cancer: the frequently recurring papillary tumor (Ta), and the more aggressive carcinoma in situ (CIS). While either type can progress into invasive tumors (T1-T4), the development of low-grade Ta tumors into the invasive cancer is unlikely, while high-grade Ta tumors and CIS can result in invasive carcinoma. Noninvasive tumors have been grouped as 'superficial bladder cancer' and are different in their behaviors from invasive tumors with basement membrane invasions [46-48]. On average, $70-80 \%$ of bladder cancers are noninvasive and patients with noninvasive or organ-confined invasive tumors $(\mathrm{T} 1 / 2, \mathrm{~N}-)$ carries receive a better prognosis than those with more advanced disease, including extravesical tumors $(\mathrm{T} 3 / 4, \mathrm{~N}-)$, tumors with lymph node metastases (any T, N+), or metastases (any T/N, M+) [47-49].

It is important to note that despite improvements in management, such as the use of chemotherapy or chemo-radiation therapy, the overall prognosis of bladder cancer has not improved over the past three decades [37-39]. For example, as of 2010, the 5 year overall survival rate for bladder cancer patients was 79.8\%, a 2.8\% increase from 1974-1986. In summary, $92.5 \%$ of patients with bladder-only disease survive for 5 years, a $4.5 \%$ increase from 1974-1986. By contrast, the current 5 year survival rates for patients with more invasive disease with invasions to extravesical area/nodal area or distant metastasis are $44.7 \%$ and $6.1 \%$, respectively, indicating a small decrease of $0.3 \%$ and $3.9 \%$, respectively, since 1974-1986. Therefore, once bladder cancer progresses beyond organ-confined disease, the chance of successful management is minimal; early detection of bladder cancer seems to be the most effective way of securing a better prognosis.

In recent years, the focus on urine-based bladder tumor markers (UBBTMs) has been aimed at reducing the frequency of invasive follow-up for patients with a prior history of bladder cancer. Ideally, a rapid, inexpensive test with strong specificity and sensitivity would best serve the target population. However, the development of such ideal tests has not been achieved yet. As discussed briefly above, cytology has been hampered by its low sensitivity for low-grade tumors [49-56]. Among the assays evaluated in the past 20 years, several warrant further discussion. These assays include the following: the bladder tumor antigen (BTA) test, BTA TRAK, BTA stat, urinary nuclear matrix protein 22 (NMP22), fibrin degradation product (FDP), autocrine motility factor receptor, bladder cancer nuclear matrix protein (BCLA-4), cytokeratin 20, telomerase, hyaluronic acid, hyaluronidase, Immunocyt, the urinary bladder cancer (UBC) test, CYFRA 21-1, chemiluminescent hemoglobin, hemoglobin dipstick, urinary tissue polypeptide-specific (TPS) antigen, bladder cancer antigen (BCA), beta-human chorionic gonadotropin, tissue polypeptide antigen (TPA), and microsatellite analysis.

\subsection{Overview: $\mathrm{MSI}$ and LOH in Bladder Cancer Detection}

UCC is characterized by the frequent loss of heterozygosity (LOH) at the following chromosomal locations: 4p, 8p, 9pq, 11p, and 17p [36,57-60]. As discussed above, MSI targets tandem repeats in genomic DNA to evaluate the loss of heterozygosity (LOH) that occurs with tumor cell transformation [60-67]. These MSI biomarkers, originally developed at Johns Hopkins University, have been shown to detect deletions in DNA isolated from the 
urine sediment of bladder cancer patients before the cytoscopic detection of tumor $[68,69]$. Several studies have shown that these microsatellite changes can be profiled in urine for the detection of bladder cancer cells [70-76]. Microsatellite analysis for bladder cancer detection is based on 15 to 20 markers from a region with a high percentage of $\mathrm{LOH}$ during the development of bladder cancer. This method proved very sensitive for low- and high-grade lesions with sensitivities of $67 \%, 86 \%$, and $93 \%$ for recurrent G1, G2, and G3 lesions, respectively, and an initial specificity of $88 \%$ [68-80]. Importantly, microsatellite analysis could predict a recurrence before cystoscopically detected evidence in all studies with extended follow-up [79]. Although microsatellite analysis (MSA) offers extremely high potential, automation of the assay, multi-center studies, and data interpretation for patients with persistent leukocyturia are crucial to make it a widely used test.

\subsection{Microsatellite Analysis: Initial Studies}

As discussed above, studies on the applicability of MSI analysis to the diagnosis of bladder tumors were first described by Mao et al. at Johns Hopkins University [69]. In this study and other studies cited below, the MSI analysis was considered positive for tumor if any one of the 15 microsatellite markers was positive in their initial report. These investigators described the analysis of urine and tumor specimens obtained from groups of individuals who had received transurethral resection of known bladder tumors (TURBT). Control specimens and material obtained from patients treated for non-malignant bladder conditions were also analyzed. After the extraction of genomic DNA from the peripheral lymphocytes of each study participant, DNA was also extracted from urine specimens obtained prior to tumor resection. DNA was also retrieved from each tumor specimen. Using a panel of microsatellite markers previously shown to be highly informative in bladder tumors, electrophoresis of the PCR products revealed a high rate of concordance between microsatellite alterations in tumors and urine specimens from the same patients. In this small initial experience, the sensitivity of MSI analysis was estimated to be $95 \%$ for the detection of various clinical stages of bladder cancer [68,69].

In a subsequent study, Steiner et al. used MSI analysis (MSA) as a monitoring tool for the surveillance of patients after treatment. Utilizing the same technology, a group of 21 patients was followed with cystoscopy, cytology, and microsatellite analysis. The investigators reported that microsatellite analysis anticipated the development of bladder tumors as long as 6 months prior to cystoscopy [77]. The rate of cancer detection exceeded $90 \%$ (10 of 11 cancers detected by MSA). The investigators also reported a specificity of $100 \%$ [80]. An additional study reported that the sensitivity and specificity of MSA on frozen archived urine samples were both over $80 \%$, which was comparable with other tests on the market [81]. Other groups have examined the diagnostic utility of microsatellite analysis within the context of bladder cancer management. Mourah et al. (1998) studied 59 patients with bladder cancer and reported an MSA sensitivity of $83 \%$ and a specificity of $100 \%$ [82]. Similarly, Steiner et al. (1999) reported a diagnostic sensitivity for their 20 marker MSA assay of 91\% [83], and Baron et al. (2000) found MSA sensitivity to be $84 \%$ in their patients with bladder cancer. Similar findings were reported among bladder cancer patients with cystitis $[84,85]$. MSA results may occasionally be confounded by intercurrent inflammatory processes, although this appears to be a rare event and requires study in a large group of patients $[85,86]$. MSA sensitivity appears to increase with stage and grade of disease in the small number of patients evaluated to date [86-88]. These studies also indicated that fewer than 20 markers can be sufficient to provide high sensitivity and specificity. In addition, the microsatellite markers employed in the MSA assay must be tailored to the population under scrutiny, as demonstrated by the initially low informativeness of the assay in Chinese patients studied using marker panels that were developed for occidental patient cohorts [87-89]. These studies suggest that as experience with MSA increases and as marker panels expand and become better defined, MSA tests will achieve high sensitivity and specificity, making them an ideal approach for a large clinical trial and, ultimately, for evaluation as a substitute for standard-of-care technology. In summary, 
based on 9 studies that tested the diagnostic accuracy of MSA as an initial diagnostic tool (Table 1A), sensitivity was 90\%, which resulted from the detection of 373 out of 417 cancer samples. Specificity was $98 \%$, which resulted from the detection of 113 out of 115 normal samples. Notably, most of these studies were performed in the early 2000s and the most recent study was performed in 2009. No meaningful report has emerged in the last 10 years.

Table 1. A: List of prior publications and sensitivity/specificity analysis on MSA study for the initial detection of bladder cancer. B: List of prior publications and sensitivity/specificity analysis on MSA study for the recurrent disease detection (surveillance setting) of bladder cancer.

\begin{tabular}{|c|c|c|c|c|}
\hline $\mathbf{A}$ & & & & \\
\hline Study & $\begin{array}{l}\text { No. of Cancers Detected } \\
\text { by MSA }\end{array}$ & $\begin{array}{c}\text { Sensitivity } \\
(\%)\end{array}$ & $\begin{array}{l}\text { Healthy Controls with } \\
\text { Neg MSA Result }\end{array}$ & $\begin{array}{l}\text { Specificity } \\
(\%)\end{array}$ \\
\hline $\begin{array}{c}\text { Mao et al. (1996) Science } \\
\text { 271:659-662 }\end{array}$ & $19 / 20$ & 95 & 5 out of 5 & 100 \\
\hline $\begin{array}{l}\text { Wild et al. (2009) } \diamond \text { Cancer Epidemiol. } \\
\text { Biomark. Prev, 18, 1798-1806 }\end{array}$ & $71 / 81$ & 88 & 37 out of 38 & 97 \\
\hline $\begin{array}{c}\text { Linn et al. (1997) Int J Cancer } \\
74: 625-629\end{array}$ & $13 / 15$ & 87 & $\mathrm{~N} / \mathrm{A}$ & $\mathrm{N} / \mathrm{A}$ \\
\hline $\begin{array}{c}\text { Schneider et al. (2000) Cancer Res } \\
60: 4617-4622\end{array}$ & $87 / 103$ & 84 & $\mathrm{~N} / \mathrm{A}$ & $\mathrm{N} / \mathrm{A}$ \\
\hline $\begin{array}{c}\text { Sourvinos et al. (2001) } \bullet \mathrm{J} \text { Urol } \\
165: 249-252\end{array}$ & $26 / 28$ & 93 & 10 out of 10 & 100 \\
\hline $\begin{array}{l}\text { Zhang et al. (2001) Cancer Lett. } \\
\qquad 172: 55-58\end{array}$ & $73 / 81$ & 90 & $19 / 19$ & 100 \\
\hline $\begin{array}{c}\text { Seripa et al. (2001) } \gg \text { Int J Cancer } \\
95: 364-369\end{array}$ & $33 / 34$ & 97 & 11 out of 11 & 100 \\
\hline Zhang et al. (2001) $\bullet$ JNCI 93:45-50 & $22 / 23$ & 96 & $17 / 17$ & 100 \\
\hline $\begin{array}{c}\text { van Rhijn et al. }(2003) \diamond \text { Clin. Cancer } \\
\text { Res. 9, 257-263 }\end{array}$ & $29 / 32$ & 91 & 14 out of 15 & 93 \\
\hline OVERALL & $373 / 417$ & $90 \%$ & $113 / 115$ & $98 \%$ \\
\hline \multicolumn{5}{|l|}{ B } \\
\hline Study & $\begin{array}{l}\text { No. of Cancers Detected } \\
\text { by MSA }\end{array}$ & $\begin{array}{l}\text { Sensitivity } \\
(\%)\end{array}$ & $\begin{array}{l}\text { Healthy Controls with } \\
\text { Neg MSA Result }\end{array}$ & $\begin{array}{l}\text { Specificity } \\
(\%)\end{array}$ \\
\hline $\begin{array}{c}\text { van Rhijn et al. (2001) } \checkmark \text { Cancer } \\
92: 768-775 . e ~ 271: 659-662\end{array}$ & $23 / 29$ & 79 & 66 out of 70 & 94 \\
\hline $\begin{array}{c}\text { Steiner et al. (1997) Nat Med. } \\
\text { 3:621-624 }\end{array}$ & $10 / 11$ & 91 & 10 out of 10 & 100 \\
\hline $\begin{array}{c}\text { Baron et al. (2000) Adv Clin Path.4 } \\
(1): 19-24\end{array}$ & $21 / 25$ & 84 & $\mathrm{~N} / \mathrm{A}$ & $\mathrm{N} / \mathrm{A}$ \\
\hline $\begin{array}{l}\text { Bartoletti et al. (2005) Oncol } \\
\text { Rep;13:531-537 }\end{array}$ & $25 / 30$ & 84 & 30 out of 30 & 100 \\
\hline $\begin{array}{l}\text { Bartoletti et al. (2006) } \\
\quad \text { Urol175:2032-2037 }\end{array}$ & $59 / 73$ & 81 & 36 out of 43 & 84 \\
\hline $\begin{array}{c}\text { Bas et al. (2003) } \bullet \text { European Urology } \\
43,369-373\end{array}$ & & 83 & & 93 \\
\hline $\begin{array}{c}\text { Frigerio et al. (2007) Int. J. Cancer } \\
\text { Res, 121, 329-338 }\end{array}$ & $59 / 63$ & 93 & 28 out of 28 & 100 \\
\hline $\begin{array}{c}\text { Mourah et al. (1998) Int. J. Cancer } \\
\text { Res. 79, 629-633. }\end{array}$ & $10 / 12$ & 96 & 15 out of 15 & 100 \\
\hline $\begin{array}{c}\text { Amira et al. (2002) } \ \text { Int J Cancer } \\
\text { 101:293-297 }\end{array}$ & $44 / 47$ & 94 & $\mathrm{~N} / \mathrm{A}$ & $\mathrm{N} / \mathrm{A}$ \\
\hline OVERALL & $251 / 290$ & $87 \%$ & $185 / 196$ & $94 \%$ \\
\hline
\end{tabular}

\subsection{Microsatellite Analysis: Follow Up Studies}

Bartoli et al. reported that out of a total of 120 patients who visited a urological office, including 73 individuals with transitional cell carcinoma and 43 individuals who served as controls [90,91], MSA was performed in the blood/urine pair using 3 multiplex 
polymerase chain reactions per patient, covering 10 MSI markers. Notably, urine sediment inflammatory cells were assessed through a urine dipstick test and an ABI Prism ${ }^{\circledR} 310$ Genetic Analyzer was used to calculate the cutoff for allelic imbalance. Out of a total of 66 patients who had microsatellite analysis alterations in their urine sediment, 59 had transitional cell carcinoma, while the test's sensitivity and specificity were $80.8 \%$ and $85.1 \%$, respectively. Notably, statistical analysis did not suggest any noticeable influence of inflammatory status by urine dipstick test on MSA performance. This study also confirmed that chromosome 9 plays a specific role in transitional cell carcinoma, since among the control samples, the allelic loss of chromosome 9 was seldom seen. This multiplex microsatellite analysis method carried a low cost and took less time than prior methods, while this study was based on 10 different markers.

Another study by Bartoli et al. showed similar findings [90,91] to their first report, while in this report, 13 MSI markers were used instead of 10 . Among 42 patients, the diagnostic accuracy of four different tests, including urinary cytology, urinary bladder cancer (UBC) marker, bladder tumor antigen (BTA), and MSA were compared. Monoclonal antibody tests were used for the UBC and BTA-t analyses, while a urinary Autocyte Preparation System ${ }^{\circledR}$ was used for the urine cytology. First, urinary cytology detected a lower number of bladder cancer cases than expected: $13.3 \%$ of tested TCC (bladder cancer) patients. Second, while $73.3 \%$ of cancer patients were detected by BTA-t marker with $50 \%$ specificity, the UBC marker detected $63.3 \%$ of cancer patients with a $41.6 \%$ specificity [90]. Third, MSA identified $83.3 \%$ of cancer patients with a $100 \%$ specificity. Fourth, and most importantly, MSA demonstrated high sensitivity among patients with superficial (81.4\%) disease or G1 (80\%) grade tumors, where cytological studies detected little or no cancer cases. This study concluded that 13 marker MSA is a highly sensitive and specific test for the initial diagnosis of TCC and recurrence monitoring, and it offers powerful diagnostic accuracy among patients with superficial, early-stage, and low-grade tumors. Frigerio et al. [72] found that cytology combined with MSA offered high sensitivity for identifying primary tumors and could detect all recurrent diseases. In a prospective study among 91 patients, LOH analysis with MSA, UroVysion FISH, and conventional urine cytology were compared with the histological findings of consecutive transurethral biopsies. Although all the samples could be analyzed by our $\mathrm{LOH}$ assay, only 56 samples were suitable for all 3 analyses. The highest sensitivity was obtained with our LOH-assay/cytology approach (G1-2: 72\%; G3: 96\%), which was only surpassed by a combination of all three techniques (G1-2: 83\%; G3: 100\%). Importantly, over $93 \%$ of the patients with recurrent disease could be detected by LOH/cytology analyses of their voided urine samples; a surveillance plan based on alternating cystoscopy with $\mathrm{LOH} /$ cytology-examination was proposed. Likewise, van Rhijn et al. [92-94] demonstrated that out of 47 Caucasian patients with confirmed superficial bladder TCC (37 pTa, 10 pT1) at initial diagnosis, MSA demonstrated a $94 \%$ (44/47) sensitivity. Overall, the studies by Bartoli, Frigerio, and van Rhijin firmly confirmed that microsatellite assay is an efficient way of detecting early stage bladder cancer.

Wild et al. reported, among 119 patients [76], diagnostic accuracy for loss of heterozygosity (LOH), FGFR3 mutation, polysomy, and p16 deletion using UroVysion FISH. From voided urine samples, initially, the three methods (CYTO, LOH, and FGFR3) were assessed individually for their diagnostic accuracy to detect bladder cancer cells in urine. Additionally, FGFR3 and LOH analysis were tested in conjunction with cytology. The combination of the three techniques (CYTO + LOH + FGFR3) did not provide significant diagnostic accuracy. However, the combination of cytology with LOH analysis (CYTO + $\mathrm{LOH}$ ) resulted in the highest diagnostic accuracy for the detection of bladder cancer cells and performed better than cytology alone (sensitivity of $88.2 \%$ and specificity of $97.1 \%$ ). The study further concluded that a combination of cytology with LOH analysis may be able to reduce the number of unpleasant cystoscopies for bladder cancer patients.

In summary, based on 9 studies that tested the diagnostic accuracy of MSA in a recurrent surveillance setting (Table 1B), sensitivity was $87 \%$, which resulted from the detection of 251 out of 290 cancer samples. Specificity was $94 \%$, which resulted from the 
detection of 185 out of 196 normal samples. Notably, most of these studies were performed in the early 2000s. No meaningful report has emerged the last 10 years. Besides, some of the studies $\{76\}$ reported data in combination with other molecular assays and are therefore not included in Table 1B.

\subsection{MSA Assay for Surveillance for Recurrent Bladder Cancer}

Several independent reports have previously suggested the higher sensitivity of MSA (75-96\%) compared to that of cytology (13-50\%) in various settings of clinical testing designs [69-90]. Unlike conventional cytology, MSA detected low-grade and low-stage disease as efficiently as it could high-grade and high-stage disease [81-98]. Amira et al. were one of the first groups who analyzed MSA results in a more comprehensive study design [79] and reported that a positive MSA test preceded a visible recurrence between 1 month and 9 months in $75 \%$ of patients in their follow up cohorts. Similarly, a report by van Riijen [99] demonstrated that, out 93 bladder cancer patients, MSA identified 18 of the 24 recurrent tumors, while the six undetected tumors turned out to be minimal pTaG1 lesions, for which early surgical treatment was not necessary. By contrast, 5 out of 9 patients with a positive MSA with a negative cystoscopy, as in the report by Amira et al., had a tumor recurrence within 6 months that was detected by cystoscope. Overall, the sensitivity $(74 \%)$ was significantly higher than that of the BTA stat test (56\%) or urine cytology $(22 \%)$.

As discussed above, Frigerio et al. [72] reported that the combined use of cytology and $\mathrm{LOH}$ analysis could detect most diseases. They obtained a sensitivity of $72 \%$ for grade $1-2$ tumors and $96 \%$ for grade 3 tumors. Likewise, van Rhijn et al. [78] demonstrated that out of 47 patients with superficial bladder TCC ( $37 \mathrm{pTa}, 10 \mathrm{pT} 1)$ at initial diagnosis, who had been followed up for 12-48 months after tumor removal, MSA provided a precise detection of cancer: $94 \%$ (44/47) of primary tumors and $92 \%(12 / 13)$ of tumor recurrences. As discussed above for two previous study reports, a majority $(5 \%(9 / 12))$ of tumor recurrences were discovered 1 to 9 months prior to cystoscopy-based detection of recurrent disease. This study's results are consistent with the notion that MSA can reliably detect superficial bladder tumors at the time of diagnosis, while it can also be used for the detection and prediction of recurrent tumors.

Notably, van Rhijn et al. performed an extensive literature review on the use of 18 markers (BTAstat, BTAtrak, NMP22, FDP, ImmunoCyt, Cytometry, Quanticyt, $\mathrm{Hb}$ dipstick, LewisX, FISH, Telomerase, MSA, CYFRA21-1, UBC, Cytokeratin20, BTA, TPS, and Cytology) in the surveillance of recurrent bladder cancer [94]. The highest median sensitivities were reported for CYFRA21-1 (85\%), Cytokeratin20 (85\%), and MSA (82\%). The highest specificities were reported for Cytology (94\%), BTA $(92 \%)$, and MSA ( $89 \%)$ (Tables 2 and 3). This report concluded that MSA, ImmunoCyt, NMP22, CYFRA21-1, LewisX, and FISH are the most promising markers for surveillance at the time of writing. Nevertheless, so far, there is not enough clinical evidence to warrant the substitution of the cystoscopic follow-up scheme by any of the currently available urine marker tests. Likewise, currently, the data are not consistent with the sole use of molecular tests in patients with a high risk of developing bladder cancer. However, many studies have shown molecular tests to offer value in not only improving the diagnostic accuracy of high-risk groups in the initial diagnosis of bladder cancer, but also in the prediction of recurrence [91-102], albeit only when used in conjunction with cytology and cystoscopy; molecular testing can reduce the need for these procedures. 
Table 2. Sensitivity and specificity of the data for various urinary biomarkers for surveillance of recurrent bladder cancer. Adapted from van Rhijn et al. [94].

\begin{tabular}{ccccccc}
\hline Marker & $\begin{array}{c}\text { Median } \\
\text { Sensitivity }\end{array}$ & $\begin{array}{c}\text { Range } \\
\text { (Min-Max) }\end{array}$ & $\begin{array}{c}5 \% \\
\text { Difference }\end{array}$ & $\begin{array}{c}\text { Median } \\
\text { Specificity }\end{array}$ & $\begin{array}{c}\text { Range } \\
\text { (Min-Max) }\end{array}$ & $\begin{array}{c}5 \% \\
\text { Difference }\end{array}$ \\
\hline BTAstat & 70 & $24-89$ & Yes & 75 & $52-93$ & - \\
\hline BTAtrak & 69 & $57-79$ & - & 65 & $48-95$ & - \\
\hline NMP22 & 73 & $47-100$ & - & 80 & $56-95$ & Yes \\
\hline FDP & 61 & $52-81$ & Yes & 79 & $75-96$ & Yes \\
\hline ImmunoCyt & 83 & $50-100$ & Yes & 80 & $69-90$ & Yes \\
\hline Cytometry & 60 & $45-83$ & - & 80 & $36-87$ & - \\
\hline Quanticyt & 59 & $45-69$ & - & 79 & $70-93$ & - \\
\hline Hb-dipstick & 52 & $41-95$ & Yes & 82 & $68-93$ & - \\
\hline LewisX & 83 & $80-89$ & Yes & 85 & $80-86$ & - \\
\hline FISH & 84 & $73-92$ & Yes & 95 & $92-100$ & Yes \\
\hline Telomerase & 75 & $7-100$ & Yes & 86 & $24-93$ & na \\
\hline Microsatellite & 91 & $83-95$ & Yes & 94 & $89-100$ & Yes \\
\hline CYFRA21-1 & 94 & $74-99$ & Yes & 86 & $67-100$ & - \\
\hline UBC & 78 & $66-87$ & Yes & 91 & $80-97$ & - \\
\hline Cytokeratin20 & 91 & $82-96$ & Yes & 84 & $67-97$ & Yes \\
\hline BTA & 50 & $28-80$ & - & 86 & $66-95$ & - \\
\hline TPS & 72 & $64-88$ & Yes & 78 & $55-95$ & - \\
\hline Cytology & 48 & $31-100$ & Yes & 94 & $62-100$ & - \\
\hline
\end{tabular}

Table 3. The median sensitivity per grade (G1-3) and specificity of the urinary biomarkers for surveillance of recurrent bladder cancer. Adapted from van Rhijn et al. [94].

\begin{tabular}{|c|c|c|c|c|}
\hline $\begin{array}{c}\text { Marker (Reference } \\
\text { Number) }\end{array}$ & $\begin{array}{l}\text { No. pts./Median } \\
\text { Sensitivity }\end{array}$ & & & $\begin{array}{l}\text { No. pts./Median } \\
\text { Specificity }\end{array}$ \\
\hline & $\mathrm{G} 1$ & G2 & G3 & \\
\hline BTAstat & $228 / 45$ & $206 / 60$ & $208 / 75$ & $972 / 79$ \\
\hline BTAtrak & $60 / 55$ & $61 / 59$ & $101 / 74$ & $195 / 66$ \\
\hline NMP22 & $56 / 41$ & $77 / 53$ & $81 / 80$ & $235 / 59$ \\
\hline FDP & $13 / 62$ & $36 / 64$ & $22 / 86$ & $113 / 80$ \\
\hline ImmunoCyt & $23 / 78$ & $10 / 90$ & $18 / 100$ & $83 / 62$ \\
\hline Cytometry & $18 / 11$ & $54 / 41$ & $38 / 66$ & $52 / 87$ \\
\hline Quanticyt & - & $11 / 64$ & $5 / 80$ & $56 / 68$ \\
\hline Hb-dipstick & $13 / 15$ & $36 / 39$ & $22 / 73$ & $113 / 87$ \\
\hline FISH & $25 / 56$ & $9 / 78$ & 20/95 & $130 / 70$ \\
\hline Microsatellite & $27 / 67$ & $21 / 86$ & $30 / 93$ & $138 / 88$ \\
\hline UBC & $29 / 38$ & $29 / 41$ & $16 / 69$ & $79 / 72$ \\
\hline Cytokeratin20 & $14 / 71$ & $35 / 80$ & $35 / 100$ & na \\
\hline BTA & $31 / 16$ & $43 / 47$ & $50 / 52$ & $91 / 91$ \\
\hline TPS & $29 / 32$ & $35 / 54$ & $15 / 74$ & $72 / 63$ \\
\hline Cytology & $239 / 17$ & $274 / 34$ & $201 / 58$ & $861 / 95$ \\
\hline
\end{tabular}

\subsection{MSA Assay as a Tool Predicting Recurrent Bladder Cancer}

Amira et al.'s report was one of the first to examine MSA results after a systemic surveillance design [79]. This study group found that a positive MSA test preceded a visible recurrent disease by 1 month to 9 months among $75 \%$ of patients under surveillance. Similarly, the report by van Riijen demonstrated that out of 93 bladder cancer patients in a surveillance setting, 5 of 9 patients with a positive MSA with a negative cystoscopy had a tumor recurrence within 6 months after urine collection [93,94]. Importantly, van der et al. reported that out of 228 patients monitored by MSA as a prospective surveillance tool, the two-year risk of developing recurrent disease reached $83 \%$ if the MSA outcome was persistently positive, while it was $22 \%$ when MSA was persistently negative [75]. Overall, the author suggested that MSA status can be used as a potentially powerful tool in predicting recurrent disease. In subset analysis, the positive predictive value of MSA 
for recurrent disease is much higher in patient groups with an FGFR3 wild-type from resected tumor samples, as it reaches $100 \%$ at 24 months of follow-up [96-98]. This finding is consistent with the observation that FGFR3 gene mutations are known to be associated with genomic stability in bladder cancer [97-103]. Notably, several studies have identified that MSA more frequently fails to detect recurrent disease among nonsmoking patients. Moreover, surveillance by MSA seems to be more efficient in the assessment of smoking patients with an FGFR3 wild-type tumor, which is genetically more unstable $[96,97]$. For patients with an FGFR3 mutant tumor, surveillance by FGFR3 mutation analysis was proposed as a potentially viable choice [96-98].

\subsection{MSA Assay for Different Ethnic Group}

Notably, the microsatellite markers employed in the MSA assay must be tailored to the population under scrutiny, as demonstrated by the initially low informativeness of the assay on Chinese patients studied using marker panels that were developed for occidental patient cohorts [104-111]. These studies suggest that as experience with MSA increases and as marker panels expand and become better defined, MSA tests will achieve high sensitivity and specificity, making them an ideal approach for a large clinical trial and, ultimately, for evaluation as a substitute for standard-of-care technology. Recent studies performed in China on STR markers have established that the heterozygosity frequencies for many of the STR markers is sufficient for LOH testing in cancer. In their report, Song et al. investigated the application of 13 short tandem repeat (STR) loci (D13S317, D7S820, TH01, D16S539, CSFIPO, VWA, D8S1179, TPOX, FGA, D3S1358, D21S11, D18S51, and D5S818) routinely used in forensic analysis for delineating population relationships among seven human populations representing the two major geographic groups, namely the southern and northern Chinese [104]. The resulting single topology suggested significant geographic and population partitioning, which was in line with the differences in geographic location, languages, and eating habits. These findings also suggest that forensic STR loci can potentially become powerful tools as they can provide the necessary fine resolution for reconstructing recent human evolutionary history. Another study tested the genetic polymorphism of 29 STR loci in the Hunan, Han population in China, and further investigated the application of short tandem repeat (STR) loci routinely used in forensic analysis in Chinese populations [111]. Both studies revealed heterozygosity frequency (HF) for FGA and TH01, two of the MSA markers most frequently used in the Chinese population. HF needs to be above $50 \%$ to be considered a good marker for MSA and TH01 and FGA showed $86 \%$ and $66 \%$ HF, respectively. The correlation of HF with STR markers in this and other studies was $>50 \%$ HF in general in STR markers in the Chinese population and, therefore, to extrapolate that expected HF in the MSA markers. We recently proposed a multiplex PCR format and proposed that 15 markers (manuscript submitted) would achieve at least five informative markers in the Chinese population in $99.995 \%$ of the patients if the HF frequency is $>50 \%$ per marker.

\subsection{Automated MSA Assay for Detection of Bladder Cancer}

$\mathrm{LOH}$ is typically identified by comparing the DNA isolated from tumors to normal DNA, such as that isolated from blood. Short tandem repeat (STR) regions, also known as microsatellite regions, within chromosomes are unstable in cancerous cells and are deleted, causing a loss of heterozygosity $(\mathrm{LOH})$ in tumor samples. This $\mathrm{LOH}$ is detected using a method known as microsatellite analysis (MSA). Traditionally, MSA is performed through the amplification of STR loci, using polymerase chain reaction (PCR) with primers flanking the STR region followed by polyacrylamide gel or capillary electrophoresis. STRs are short sequences of DNA, normally 2-5 base pairs in length, that are repeated numerous times in a head-tail manner, i.e., the $16 \mathrm{bp}$ sequence of "gatagatagatagata" would represent four head-tail copies of the tetramer "gata". The number of repeats in STRs varies not only from person to person but from one allele to another within the same person. Therefore, a person may possess six sets of a tetramer repeat on one allele and ten on the other allele; this 
person is said to be heterozygous at this STR region. PCR amplification of a heterozygous STR yields PCR products of two different sizes. Furthermore, these STR regions become unstable during cancer progression and may be lost due to deletion. When this loss occurs, only one PCR product is amplified in the tumor. Comparison of the normal DNA (isolated from peripheral blood) and the tumor specimen shows a loss of heterozygosity (LOH) in the tumor specimen (Figure 2). In this manner, a comparison of the normal DNA with the tumor DNA can detect the genetic changes indicative of cancerous lesions.

There are three separate steps involved. First, polymerase chain reaction (PCR) amplification of the STR markers of matched blood and urine sediment genomic DNA: PCR is accomplished through PCR amplification using primer sets that flank the target STRs at 15 microsatellite loci. The $5^{\prime}$ end of each primer pair is fluorescently labeled to allow for detection of the PCR fragments by capillary electrophoresis. Second, in fluorescence-based fragment detection of the amplicons, the PCR amplicons are resolved on a capillary-based gel electrophoresis system that detects, sizes, and determines the relative fluorescence units (RFU) for each fragment. Third, in the determination of microsatellite instability status of each sample, the RFUs of heterozygous alleles detected in the blood are compared to the RFUs detected in the matched urine sample, and the ratio of RFUs from urine alleles to blood alleles is calculated. Markers that exhibit values outside the ratios seen in normal samples are said to exhibit a loss of heterozygosity $(\mathrm{LOH})$. This $\mathrm{LOH}$ serves as an indicator of bladder cancer.

A new approach that combines a PCR with fluorescent primers and capillary electrophoresis, which is performed by automatic DNA sequencer allowing fragment analysis at single base resolution has been pursued. This approach has also been modified by the multiplexing of PCR to allow the amplification of 2-5 microsatellite markers and the automatic identification of the allele size [112-120]. Clearly, this approach has been applied into MSA for bladder cancer detection. Barlott et al. [91,92] produced the first report using multiplex PCR for MSA. This group evaluated the feasibility of MSA using MPX PCR with fluorescent markers as a way of developing a simple, inexpensive method of high-sensitivity urine sediment diagnosis of TCC. Three sets of PCR tube were used in their study: Chromosome Analyzed Locus Analyzed MPX PCR 1: 9p23-p22 D9S162 9p22 IFN- 9p21 D9S171 9p21-p22 D9S747 MPX, PCR 2: 4q2.8 FGA 4pter-qter D4S243 16pter-qter D16S310 18q21.33 D18S51, and Single PCR: 18q23-qter MBP-LW 18 MBP-H. In this study, Barlott et al. [92] reported the test sensitivity and specificity to be $80.8 \%$ and $85.1 \%$, respectively. The study suggested that multiplex microsatellite analysis can be a noninvasive, rapid, inexpensive, and reproducible method for screening for and monitoring superficial transitional cell carcinoma.

Most current microsatellite analyses are designed to compare the ratios of amplification products of the paternal and the maternal allele from the urine samples of patients against the ratios from their blood leukocytes as normal control, judging values below a range of $0.5-0.7$ and over 1.5-2, respectively, as indications of a $\mathrm{LOH} /$ allelic imbalance. These thresholds were arbitrarily set and consequently did not take into account technical influences, such as differences in DNA quality and quantity between control and test samples or locus-specific amplification reproducibility, and could result in inconsistent findings in different groups. The thresholds also caused decreased sensitivity and sensitivity. Therefore, not only a good selection of informative markers but also the right ratio is crucial in developing a dependable MSA for bladder cancer detection. Commonly applied parameters are suggested based on rather conservative estimates to avoid false positives and thereby to secure a relatively high specificity, resulting in reduced sensitivity (minimal proportion of $35-50 \%$ tumor cells required).

To address this problem more systematically, Frigorie et al. experimentally determined individual threshold values for 10 STR-markers commonly affected in urothelial tumors by first comparing a large set of DNAs from normal human control tissues among themselves [72]. The threshold values from a retrospective study on biopsies from confirmed bladder carcinoma patients were tested in a blinded prospective survey for the sensitivity 
and specificity of MSA and these data were further compared with conventional cytological and UroVysion FISH analyses that were performed in parallel. PCR was performed for each patient. The authors proposed the 10 most informative markers. These included 5 marker loci on chromosome 9 (IFNA, D9S925, D9S162, D9S938, D9S747) previously linked to early tumor development and a set of markers on chromosome 17p (TP53, D17S960), 8p (D8S261), 13q (D13S155), and 16q (D16S476) [121-124]. The report also included a new threshold for each marker; ratios below 0.8 were linked to an $\mathrm{LOH}$ for the highly reproducible markers IFNA, D9S747, D16S476, and D17S960, while LOH thresholds between 0.5 and 0.7 were obtained for the technically less reliable marker amplifications of the microsatellite loci D8S261, D9S162, D9S925, D13S155, and TP53.

\section{Discussion}

Its multifaceted clinical presentation and expected course of progression make bladder cancer a potentially valuable screening target; currently, the consensus is that high-risk populations should be screened $[39,40]$. Two key aspects underscore the importance of bladder cancer screening in the coming decades. First, the persistently high prevalence of smoking is expected to function as key hazard for significant carcinogenic effects on the bladder for the next several generations. Second, it is highly unlikely for bladder cancer to have the capacity to metastasize before it becomes invasive [47]. Therefore, there is a valuable opportunity to detect bladder cancer early, in a window of timing between tumor origination and invasion. Certainly, the management of noninvasive cancers involves fewer morbidities and is more effective for curative treatment than that of invasive bladder cancer [51] as, in this stage of tumor development, cystectomy, systemic chemotherapy or chemo-radiation therapy are not required.

MSA for the detection of cancer poses several significant technical challenges, specifically in the area of allele calling and interpretation. The results obtained mirror the results obtained by Butler et al. during validation studies for STR analysis for human identity. Laboratory-to-laboratory variability due to instrumentation and personnel created differences in assay performance. Additionally, both stochastic effects and variations in peak height effects between the DNA derived from urine sediment samples and the DNA derived from blood samples provided more variation in the results, which added to interpretation differences. These differences were especially evident in samples that produced results slightly above or below the cut-off ratios established for $\mathrm{LOH}$. Hence, STR assays present significant challenges, including establishing the parameters to be used for determining $\mathrm{LOH}$ from potential tumor cells isolated from urine sediment.

LOH is commonly observed among many different types of solid tumors and allows the detection of recessive loss-of-function mutations in tumor suppressor genes [57-60]. The detection of recurrent $\mathrm{LOH}$ in a genomic region is critical evidence for the localization of tumor suppressor genes. Multiple factors play a role in interpretation because most clinical samples collected from urine contain a mixture of tumor and normal cells, producing a potential mixture at each loci being analyzed, which can obscure losses of genetic material in tumor cells. Moreover, $\mathrm{LOH}$ can only be determined by comparative analysis of a control profile obtained from a blood sample. This study illustrates the challenge of qualifying a technically difficult biomarker assay that requires interpretation by an analyst. Recently, we successfully reproduced a dependable 15 marker, 3 multiplex PCR assay. Additionally, we are preparing a manuscript for a concordance study between three laboratories and two different genetic analyzers. Moreover, we are also preparing a report on a unique approach to MSA involving the use of genomic DNA from a buccal swab instead of blood samples. This new approach will be likely to be patient-friendly as this will clearly avoid unnecessary blood sampling.

As discussed extensively above, many independent groups previously confirmed the superior sensitivity of MSA (75-96\%) compared to cytology (13-50\%) in various clinical settings [57-102] and, based on 18 different studies from 1997 to 2009, the sensitivity was approximately $90 \%$ and the specificity was close to $95 \%$ to $100 \%$ percent, depending on 
the clinical setting (Table 1). Unlike conventional cytology, it appears that microsatellite analysis, MSA, can detect low-grade and low-stage disease as accurately as high-grade and high-stage disease [68-81]. As discussed above, Frigerio et al. [72] reported that the combined use of cytology and LOH analysis by MSA carried high sensitivity for identifying primary tumors as well as for detecting almost all recurrent diseases. Likewise, van Rhijn et al. [92-94] analyzed 47 Caucasian patients with confirmed superficial bladder TCC (37 pTa, $10 \mathrm{pT} 1$ ) at initial diagnosis and proposed three important observations on MSA. First, MSA correctly identified $94 \%$ (44/47) of primary tumors. Second, MSA correctly identified $92 \%(12 / 13)$ of tumor recurrences. Third, MSA predicted the chance of future recurrences $75 \%$ of the time $(9 / 12)$; the tumor recurrences were molecularly detected 1-9 months before cystoscopy evidence of recurrent disease.

Several factors are involved in maximizing the sensitivity and specificity of MSA. First, by establishing a robust genetic marker profile and determining for each of the analyzed microsatellites individual marker threshold values for $\mathrm{LOH} /$ allelic imbalance, the sensitivity of tumor DNA detection can be achieved without compromising its specificity. Second, a careful set-up of dependable methods is necessary to avoid erroneous $\mathrm{LOH}$ judgements due to PCR artefacts, repeatedly described by others. Third, performing MSA on a genetic analyzer, which is a commonly used tool, needs to be standard in MSA practice, since it offers two major advantages. First, sample processing can be largely automatized, and results are provided in the form of a numerical data readout, independently of interobserver variability associated with the complex interpretation of morphological features. Moreover, the determination of $\mathrm{LOH}$ ratios on this platform is highly reproducible and provides reliable results even in situations when the cell conservation is suboptimal for cytological evaluation and/or FISH. In a way, the use of a standard genetic analyzer such as the ABI 3500 machine provides MSA with a significant advantage as MSA is affected little by changes in PCR conditions or the amount of genomic DNA applied. Third, the amount of genomic DNA to be analyzed needs to be sufficient; we suggest the use of least 20 to $30 \mathrm{ng}$ of urine genomic DNA, $20 \mathrm{ng}$ for 10 markers, and $30 \mathrm{ng}$ for 15 markers. Fourth, we propose that at least $15 \mathrm{~mL}$ of urine should result in more than 855 of samples with enough urine DNA. In summary, while the field of MSA-based bladder cancer detection has been quite inactive in the last 8 to 9 years, it is still a viable option as a powerful biomarker for bladder cancer detection. However, as mentioned above, four key technical considerations need to be carefully addressed in order for this to be the case.

In summary, in this review, based on over 18 publications with approximately 900 sample cohorts, we provided the sensitivity ( $87 \%$ to $90 \%$ ) and specificity ( $94 \%$ to $98 \%$ ) of MSA. We also provided a comparative analysis between MSA and other assays, as well while as discussing the details of four different FDA-approved assays. We suggest that MSA can be a potentially powerful test for bladder cancer detection and may improve the quality of life of bladder cancer patients.

Author Contributions: C.M. was the Principal Investigator of the grant that supported this project. C.M., D.M. and T.R. conceived of and executed the overall design of the review and the data collection. C.M., M.G. and D.M. wrote the paper. All authors have read and agreed to the published version of the manuscript.

Funding: This study was supported in part by the Cancer Research Grant from Pyung-Ya Foundation (grant number PY-1; to C.S.M. 1 January 2006) and the Translational Research Grant from HJM Foundation (grant number HJM-TR1; to C.S.M. and D.M. 1 January 2019).

Institutional Review Board Statement: Not applicable.

Informed Consent Statement: Not applicable.

Data Availability Statement: The datasets generated and/or analyzed during the current study are not publicly available as there are no public repositories for this type of dataset. The data are available from the corresponding author on reasonable request. The data supporting reported review was obtained from public data base which were found by searching google scholar or google. 
Acknowledgments: C.M. is deeply indebted to H J Moon for his encouragement for the completion of this study.

Conflicts of Interest: C.M. is founding shareholder of BCD Innovations and T.R. is founding shareholder of Next Molecular Bio. M.G. and D.M. both declare no conflicts of interest.

\section{References}

1. Aaltonen, L.A.; Peltomäki, P.; Leach, F.S.; Sistonen, P.; Pylkkänen, L.; Mecklin, J.P.; Järvinen, H.; Powell, S.M.; Jen, J.; Hamilton, S.R.; et al. Clues to the pathogenesis of familial colorectal cancer. Science 1993, 260, 812-816. [CrossRef]

2. Ionov, Y.; Peinado, M.A.; Malkhosyan, S.; Shibata, D.; Perucho, M. Ubiquitous somatic mutations in simple repeated sequences reveal a new mechanism for colonic carcinogenesis. Nature 1993, 363, 558-561. [CrossRef]

3. Thibodeau, S.; Bren, G.; Schaid, D. Microsatellite instability in cancer of the proximal colon. Science 1993, 260, 816-819. [CrossRef] [PubMed]

4. Imai, K.; Yamamoto, H. Carcinogenesis and microsatellite instability: The interrelationship between genetics and epigenetics. Carcinogenesis 2008, 29, 673-680. [CrossRef] [PubMed]

5. Yamamoto, H.; Adachi, Y.; Taniguchi, H.; Kunimoto, H.; Nosho, K.; Suzuki, H.; Shinomura, Y. Interrelationship between microsatellite instability and microRNA in gastrointestinal cancer. World J. Gastroenterol. 2012, 18, 2745-2755. [CrossRef]

6. Yamamoto, H.; Watanabe, Y.; Maehata, T.; Morita, R.; Yoshida, Y.; Oikawa, R.; Ishigooka, S.; Ozawa, S.-I.; Matsuo, Y.; Hosoya, K.; et al. An updated review of gastric cancer in the next-generation sequencing era: Insights from bench to bedside and vice versa. World J. Gastroenterol. 2014, 20, 3927-3937. [CrossRef]

7. Yamamoto, H.; Imai, K. Microsatellite instability: An update. Arch. Toxicol. 2015, 89, 899-921. [CrossRef] [PubMed]

8. Gelsomino, F.; Barbolini, M.; Spallanzani, A.; Pugliese, G.; Cascinu, S. The evolving role of microsatellite instability in colorectal cancer: A review. Cancer Treat. Rev. 2016, 51, 19-26. [CrossRef]

9. de la Chapelle, A.; Hampel, H. Clinical relevance of microsatellite instability in colorectal cancer. J. Clin. Oncol. 2010, 28, 3380-3387. [CrossRef]

10. Bacher, J.W.; Flanagan, L.A.; Smalley, R.L.; Nassif, N.A.; Burgart, L.J.; Halberg, R.B.; Megid, W.M.A.; Thibodeau, S.N. Development of a fluorescent multiplex assay for detection of MSI-High tumors. Dis. Markers 2004, 20, 237-250. [CrossRef]

11. Kim, T.-M.; Laird, P.W.; Park, P.J. The landscape of microsatellite instability in colorectal and endometrial cancer genomes. Cell 2013, 155, 858-868. [CrossRef] [PubMed]

12. Lu, Y.; Soong, T.D.; Elemento, O. A novel approach for characterizing microsatellite instability in cancer cells. PLoS ONE 2013, 8 , e63056. [CrossRef]

13. McIver, L.J.; Fonville, N.C.; Karunasena, E.; Garner, H.R. Microsatellite genotyping reveals a signature in breast cancer exomes. Breast Cancer Res. Treat. 2014, 145, 791-798. [CrossRef]

14. Niu, B.; Ye, K.; Zhang, Q.; Lu, C.; Xie, M.; McLellan, M.D.; Wendl, M.C.; Ding, L. MSIsensor: Microsatellite instability detection using paired tumor-normal sequence data. Bioinformatics 2014, 30, 1015-1016. [CrossRef] [PubMed]

15. Salipante, S.J.; Scroggins, S.M.; Hampel, H.L.; Turner, E.H.; Pritchard, C.C. Microsatellite instability detection by next generation sequencing. Clin. Chem. 2014, 60, 1192-1199. [CrossRef]

16. Huang, M.N.; McPherson, J.R.; Cutcutache, I.; Teh, B.T.; Tan, P.; Rozen, S.G. MSIseq: Software for assessing microsatellite instability from catalogs of somatic mutations. Sci. Rep. 2015, 5, 13321. [CrossRef]

17. Yamamoto, H.; Imai, K.; Perucho, M. Gastrointestinal cancer of the microsatellite mutator phenotype pathway. J. Gastroenterol. 2002, 37, 153-163. [CrossRef]

18. Perucho, M. Tumors with microsatellite instability: Many mutations, targets and paradoxes. Oncogene 2003, 22, 2223-2225. [CrossRef] [PubMed]

19. Oda, S.; Zhao, Y.; Maehara, Y. Microsatellite instability in gastrointestinal tract cancers: A brief update. Surg. Today 2005, 35, 1005-1015. [CrossRef] [PubMed]

20. Söreide, K.; Janssen, E.A.M.; Söiland, H.; Körner, H.; Baak, J.P.A. Microsatellite instability in colorectal cancer. Br. J. Surg. 2006, 93, 395-406. [CrossRef]

21. Suzuki, K.; Suzuki, I.; Leodolter, A.; Alonso, S.; Horiuchi, S.; Yamashita, K.; Perucho, M. Global DNA demethylation in gastrointestinal cancer is age dependent and precedes genomic damage. Cancer Cell 2006, 9, 199-207. [CrossRef] [PubMed]

22. Smith, G.; Carey, F.A.; Beattie, J.; Wilkie, M.J.V.; Lightfoot, T.J.; Coxhead, J.; Garner, R.C.; Steele, R.J.C.; Wolf, C.R. Mutations in APC, Kirsten-ras, and p53-alternative genetic pathways to colorectal cancer. Proc. Natl. Acad. Sci. USA 2002, 99, 9433-9438. [CrossRef]

23. Vilar, E.; Gruber, S.B. Microsatellite instability in colorectal cancer-the stable evidence. Nat. Rev. Clin. Oncol. 2010, 7, 153-162. [CrossRef] [PubMed]

24. Puliga, E.; Corso, S.; Pietrantonio, F.; Giordano, S. Microsatellite instability in Gastric Cancer: Between lights and shadows. Cancer Treat Rev. 2021, 95, 102175. [CrossRef] [PubMed]

25. Le, D.T.; Uram, J.N.; Wang, H.; Bartlett, B.R.; Kemberling, H.; Eyring, A.D.; Skora, A.D.; Luber, B.S.; Azad, N.S.; Laheru, D.; et al. PD-1 blockade in tumors with mismatch-repair deficiency. N. Engl. J. Med. 2015, 372, 2509-2520. [CrossRef] 
26. Timmermann, B.; Kerick, M.; Roehr, C.; Fischer, A.; Isau, M.; Boerno, S.T.; Wunderlich, A.; Barmeyer, C.; Seemann, P.; Koenig, J.; et al. Somatic mutation profiles of MSI and MSS colorectal cancer identified by whole exome next generation sequencing and bioinformatics analysis. PLoS ONE 2010, 5, e15661. [CrossRef]

27. Woerner, S.M.; Yuan, Y.P.; Benner, A.; Korff, S.; von Knebel Doeberitz, M.; Bork, P. SelTarbase, a database of human mononucleotide-microsatellite mutations and their potential impact to tumorigenesis and immunology. Nucleic Acids Res. 2010, 38, D682-D689. [CrossRef]

28. Boland, C.R.; Thibodeau, S.N.; Hamilton, S.R.; Sidransky, D.; Eshleman, J.R.; Burt, R.W.; Meltzer, S.J.; Rodriguez-Bigas, M.A.; Fodde, R.; Ranzani, G.N.; et al. A National Cancer Institute Workshop on Microsatellite Instability for cancer detection and familial predisposition: Development of international criteria for the determination of microsatellite instability in colorectal cancer. Cancer Res. 1998, 58, 5248-5257. [PubMed]

29. Onda, M.; Nakamura, I.; Suzuki, S.; Takenoshita, S.; Brogren, C.H.; Stampanoni, S.; Li, D.; Rampino, N. Microsatellite instability in thyroid cancer: Hot spots, clinicopathological implications, and prognostic significance. Clin. Cancer Res. 2001, 7, $3444-3449$.

30. Forgacs, E.; Wren, J.D.; Kamibayashi, C.; Kondo, M.; Xu, X.L.; Markowitz, S.; Tomlinson, G.E.; Muller, C.Y.; Gazdar, A.F.; Garner, H.R.; et al. Searching for microsatellite mutations in coding regions in lung, breast, ovarian and colorectal cancers. Oncogene 2001, 20, 1005-1009. [CrossRef]

31. Duval, A.; Reperant, M.; Compoint, A.; Seruca, R.; Ranzani, G.N.; Iacopetta, B.; Hamelin, R. Target gene mutation profile differs between gastrointestinal and endometrial tumors with mismatch repair deficiency. Cancer Res. 2002, 62, 1609-1612. [PubMed]

32. Mori, Y.; Sato, F.; Selaru, F.M.; Olaru, A.; Perry, K.; Kimos, M.C.; Tamura, G.; Matsubara, N.; Wang, S.; Xu, Y.; et al. Instabilotyping reveals unique mutational spectra in microsatellite-unstable gastric cancers. Cancer Res. 2002, 62, 3641-3645. [PubMed]

33. Sonay, T.B.; Koletou, M.; Wagner, A. A survey of tandem repeat instabilities and associated gene expression changes in 35 colorectal cancers. BMC Genomics 2015, 16, 702.

34. Yoon, K.; Lee, S.; Han, T.-S.; Moon, S.Y.; Yun, S.M.; Kong, S.-H.; Jho, S.; Choe, J.; Yu, J.; Lee, H.-J.; et al. Comprehensive genomeand transcriptome-wide analyses of mutations associated with microsatellite instability in Korean gastric cancers. Genome Res. 2013, 23, 1109-1117. [CrossRef]

35. Umar, A.; Boland, C.R.; Terdiman, J.P.; Syngal, S.; de la Chapelle, A.; Rüschoff, J.; Fishel, R.; Lindor, N.M.; Burgart, L.J.; Hamelin, R.; et al. Revised Bethesda Guidelines for hereditary nonpolyposis colorectal cancer (Lynch syndrome) and microsatellite instability. J. Natl. Cancer Inst. 2004, 96, 261-268. [CrossRef] [PubMed]

36. Pasin, E.; Josephson, D.Y.; Mitra, A.P.; Cote, R.J.; Stein, J.P. Superficial bladder cancer: An update on etiology, molecular development, classification, and natural history. Rev. Urol. 2008, 10, 31-43.

37. Jemal, A.; Siegel, R.; Ward, E.; Hao, Y.; Xu, J.; Thun, M.J. Cancer statistics, 2009. Cancer J. Clin. 2009, 59, 225-249. [CrossRef]

38. Botteman, M.F.; Pashos, C.L.; Redaelli, A.; Laskin, B.; Hauser, R. The health economics of bladder cancer. PharmacoEconomics 2003, 22, 1315-1330. [CrossRef]

39. Lotan, Y.; Kamat, A.M.; Porter, M.P.; Robinson, V.L.; Shore, N.; Jewett, M.; Schelhammer, P.F.; White, R.D.; Quale, D.; Lee, C.T. Key concerns about the current state of bladder cancer. Cancer 2009, 115, 4096-4103. [CrossRef]

40. Lotan, Y.; Svatek, R.S.; Malats, N. Screening for bladder cancer: A perspective. World J. Urol. 2008, 26, 13-18. [CrossRef]

41. Shariat, S.F.; Lotan, Y.; Vickers, A.; Karakiewicz, P.I.; Schmitz-Dräger, B.J.; Goebell, P.J.; Malats, N. Statistical consideration for clinical biomarker research in bladder cancer. Urol. Oncol. 2010, 28, 389-400. [CrossRef] [PubMed]

42. Lotan, Y.; Roehrborn, C.G. Sensitivity and specificity of commonly available bladder tumor markers versus cytology: Results of a comprehensive literature review and meta-analyses. Urology 2003, 61, 109-118. [CrossRef]

43. Bensalah, K.; Montorsi, F.; Shariat, S.F. Challenges of cancer biomarker profiling. Eur. Urol. 2007, 52, 1601-1609. [CrossRef] [PubMed]

44. Babjuk, M.; Oosterlinck, W.; Sylvester, R.; Kaasinen, E.; Böhle, A.; Palou-Redorta, J.; Rouprêt, M. EAU guidelines on non-muscleinvasive urothelial carcinoma of the bladder, the 2011 update. Eur. Urol. 2011, 59, 997-1008. [CrossRef]

45. Hall, M.C.; Chang, S.S.; Dalbagni, G.; Pruthi, R.S.; Seigne, J.D.; Skinner, E.C.; Wolf, J.S.; Schellhammer, P.F. Guideline for the management of nonmuscle invasive bladder cancer (Stages Ta, T1, and Tis): 2007 Update. J. Urol. 2007, 178, 2314-2330. [CrossRef]

46. Mitra, A.P.; Datar, R.H.; Cote, R.J. Molecular pathways in invasive bladder cancer: New insights into mechanisms, progression, and target identification. J. Clin. Oncol. 2006, 24, 5552-5564. [CrossRef]

47. Mitra, A.P.; Cote, R.J. Molecular pathogenesis and diagnostics of bladder cancer. Annu. Rev. Pathol. 2009, 4, 251-285. [CrossRef]

48. Bryan, R.T.; Wallace, D.M.A. 'Superficial' bladder cancer-time to uncouple pT1 tumours from pTa tumours. BJU Int. 2002, 90, 846-852. [CrossRef]

49. Stein, J.P.; Lieskovsky, G.; Cote, R.; Groshen, S.; Feng, A.-C.; Boyd, S.; Skinner, E.; Bochner, B.; Thangathurai, D.; Mikhail, M.; et al. Radical cystectomy in the treatment of invasive bladder cancer: Long-term results in 1054 patients. J. Clin. Oncol. 2001, 19, 666-675. [CrossRef]

50. Foresman, W.H.; Messing, E.M. Bladder cancer: Natural history, tumor markers, and early detection strategies. Semin. Surg. Oncol. 1997, 13, 299-306. [CrossRef]

51. Parekh, D.J.; Bochner, B.H.; Dalbagni, G. Superficial and muscle-invasive bladder cancer: Principles of management for outcomes assessments. J. Clin. Oncol. 2006, 24, 5519-5527. [CrossRef]

52. Wakui, M.; Shiigai, T. Urinary tract cancer screening through analysis of urinary red blood cell volume distribution. Int. J. Urol. 2000, 7, 248-253. [CrossRef] [PubMed] 
53. Grossfeld, G.D.; Wolf, J.S., Jr.; Litwan, M.S.; Hricak, H.; Shuler, C.L.; Agerter, D.C.; Carroll, P.R. Asymptomatic microscopic hematuria in adults: Summary of the AUA best practice policy recommendations. Am. Fam. Physician 2001, 63, 1145-1154. [PubMed]

54. Messing, E.M.; Young, T.B.; Hunt, V.B.; Wehbie, J.M.; Rust, P. Urinary tract cancers found by homescreening with hematuria dipsticks in healthy men over 50 years of age. Cancer 1989, 64, 2361-2367. [CrossRef]

55. Messing, E.M.; Young, T.B.; Hunt, V.B.; Newton, M.A.; Bram, L.L.; Vaillancourt, A.; Hisgen, W.J.; Greenberg, E.B.; Kuglitsch, M.E.; Wegenke, J.D. Hematuria home screening: Repeat testing results. J. Urol. 1995, 154, 57-61. [CrossRef]

56. Messing, E.M.; Young, T.B.; Hunt, V.B.; Roecker, E.B.; Vaillancourt, A.M.; Hisgen, W.J.; Greenberg, E.B.; Kuglitsch, M.E.; Wegenke, J.D. Home screening for hematuria: Results of a multi-clinic study. J. Urol. 1992, 148, 289-292. [CrossRef]

57. Moon, J.J.; Lu, A.; Moon, C. Role of genomic instability in human carcinogenesis. Exp. Biol. Med. 2019, 244, 227-240. [CrossRef]

58. Saran, K.K.; Gould, D.; Godec, C.J.; Verma, R.S. Genetics of bladder cancer. J. Mol. Med. 1996, 74, 441-445. [CrossRef] [PubMed]

59. Skacel, M.; Pettay, J.D.; Tsiftsakis, E.K.; Procop, G.W.; Biscotti, C.V.; Tubbs, R.R. Validation of a multicolor interphase fluorescence in situ hybridization assay for detection of transitional cell carcinoma on fresh and archival thin-layer, liquid-based cytology slides. Anal. Quant. Cytol. Histol. 2001, 23, 381-387.

60. Lopez-Beltran, A.; Amin, M.B.; Oliveira, P.S.; Montironi, R.; Algaba, F.; McKenney, J.K.; de Torres, I.; Mazerolles, C.; Wang, M.; Cheng, L. Urothelial carcinoma of the bladder, lipid cell variant: Clinicopathologic findings and LOH analysis. Am. J. Surg. Pathol. 2010, 34, 371-376. [CrossRef] [PubMed]

61. Ploussard, G.; Dubosq, F.; Soliman, H.; Verine, J.; Desgrandchamps, F.; De Thé, H.; Mongiat-Artus, P. Prognostic value of loss of heterozygosity at chromosome 9p in non-muscle-invasive bladder cancer. Urology 2010, 76, 513.e513-513.e518. [CrossRef]

62. Cai, T.; Nesi, G.; Canto, M.D.; Mondaini, N.; Mauro, P.; Bartoletti, R. Prognostic role of loss of heterozygosity on chromosome 18 in patients with low-risk nonmuscle-invasive bladder cancer: Results from a prospective study. J. Surg. Res. 2010, 161, 89-94. [CrossRef] [PubMed]

63. Sibley, K.; Cuthbert-Heavens, D.; Knowles, M.A. Loss of heterozygosity at 4p16.3 and mutation of FGFR3 in transitional cell carcinoma. Oncogene 2001, 20, 686-691. [CrossRef]

64. Yoon, D.-S.; Li, L.; Zhang, R.-D.; Kram, A.; Ro, J.Y.; Johnston, D.; Grossman, H.B.; Scherer, S.; Czerniak, B. Genetic mapping and DNA sequence-based analysis of deleted regions on chromosome 16 involved in progression of bladder cancer from occult preneoplastic conditions to invasive disease. Oncogene 2001, 20, 5005-5014. [CrossRef]

65. Docimo, S.G.; Chow, N.-H.; Steiner, G.; Silver, R.I.; Rodriguez, R.; Kinsman, S.; Sidransky, D.; Schoenberg, M. Detection of adenocarcinoma by urinary microsatellite analysis after augmentation cystoplasty. Urology 1999, 54, 561. [CrossRef]

66. Szarvas, T. The diagnostic value of microsatellite $\mathrm{LOH}$ analysis and the prognostic relevance of angiogenic gene expression in urinary bladder cancer. Magy. Onkol. 2009, 53, 385-389. [CrossRef] [PubMed]

67. Bartoletti, R.; Cai, T.; Nesi, G.; Roberta Girardi, L.; Baroni, G.; Dal Canto, M. Loss of P16 expression and chromosome 9p21 LOH in predicting outcome of patients affected by superficial bladder cancer. J. Surg. Res. 2007, 143, 422-427. [CrossRef]

68. Ørntoft, T.F.; Wolf, H. Molecular alterations in bladder cancer. Urol. Res. 1998, 26, 223-233. [CrossRef] [PubMed]

69. Mao, L.; Schoenberg, M.P.; Scicchitano, M.; Erozan, Y.S.; Merlo, A.; Schwab, D.; Sidransky, D. Molecular detection of primary bladder cancer by microsatellite analysis. Science 1996, 271, 659-662. [CrossRef]

70. Ellegren, H. Microsatellites: Simple sequences with complex evolution. Nat. Rev. Genet. 2004, 5, 435-445. [CrossRef]

71. Seripa, D.; Parrella, P.; Gallucci, M.; Gravina, C.; Papa, S.; Fortunato, P.; Alcini, A.; Flammia, G.; Lazzari, M.; Fazio, V.M. Sensitive detection of transitional cell carcinoma of the bladder by microsatellite analysis of cells exfoliated in urine. Int. J. Cancer Res. 2001, 95, 364-369.

72. Frigerio, S.; Padberg, B.C.; Strebel, R.T.; Lenggenhager, D.M.; Messthaler, A.; Abdou, M.-T.; Moch, H.; Zimmermann, D.R. Improved detection of bladder carcinoma cells in voided urine by standardized microsatellite analysis. Int. J. Cancer Res. 2007, 121, 329-338. [CrossRef] [PubMed]

73. Hoque, M.O.; Lee, J.; Begum, S.; Yamashita, K.; Engles, J.M.; Schoenberg, M.; Westra, W.H.; Sidransky, D. High-throughput molecular analysis of urine sediment for the detection of bladder cancer by high-density single-nucleotide polymorphism array. Cancer Res. 2003, 63, 5723-5726. [PubMed]

74. de Bekker-Grob, E.W.; van der Aa, M.N.M.; Zwarthoff, E.C.; Eijkemans, M.J.C.; van Rhijn, B.W.; van der Kwast, T.H.; Steyerberg, E.W. Non-muscle-invasive bladder cancer surveillance for which cystoscopy is partly replaced by microsatellite analysis of urine: A cost-effective alternative? BJU Int. 2009, 104, 41-47. [CrossRef] [PubMed]

75. van der Aa, M.N.M.; Zwarthoff, E.C.; Steyerberg, E.W.; Boogaard, M.W.; Nijsen, Y.; van der Keur, K.A.; van Exsel, A.J.A.; Kirkels, W.J.; Bangma, C.; van der Kwast, T.H. Microsatellite analysis of voided-urine samples for surveillance of low-grade non-muscle-invasive urothelial carcinoma: Feasibility and clinical utility in a prospective multicenter study (cost-effectiveness of follow-up of urinary bladder cancer trial [CEFUB]). Eur. Urol. 2009, 55, 659-668.

76. Wild, P.J.; Fuchs, T.; Stoehr, R.; Zimmermann, D.; Frigerio, S.; Padberg, B.; Steiner, I.; Zwarthoff, E.C.; Burger, M.; Denzinger, S.; et al. Detection of urothelial bladder cancer cells in voided urine can be improved by a combination of cytology and standardized microsatellite analysis. Cancer Epidemiol. Biomark. Prev. 2009, 18, 1798-1806. [CrossRef] [PubMed]

77. Steiner, G.; Schoenberg, M.P.; Linn, J.F.; Mao, L.; Sidransky, D. Detection of bladder cancer recurrence by microsatellite analysis of urine. Nat. Med. 1997, 3, 621-624. [CrossRef] 
78. van Rhijn, B.W.G.; Lurkin, I.; Kirkels, W.J.; van der Kwast, T.H.; Zwarthoff, E.C. Microsatellite analysis? DNA test in urine competes with cystoscopy in follow-up of superficial bladder carcinoma. Cancer 2001, 92, 768-775. [CrossRef]

79. Amira, N.; Mourah, S.; Rozet, F.; Teillac, P.; Fiet, J.; Aubin, P.; Cortesse, A.; Desgrandchamps, F.; Le Duc, A.; Cussenot, O.; et al. Non-invasive molecular detection of bladder cancer recurrence. Int. J. Cancer Res. 2002, 101, 293-297. [CrossRef]

80. Schmitz-Dräger, B.J.; Beiche, B.; Tirsar, L.-A.; Schmitz-Dräger, C.; Bismarck, E.; Ebert, T. Immunocytology in the assessment of patients with asymptomatic microhaematuria. Eur. Urol. 2008, 51, 1582-1588. [CrossRef]

81. Linn, J.F.; Lango, M.; Halachmi, S.; Schoenberg, M.P.; Sidransky, D. Microsatellite analysis and telomerase activity in archived tissue and urine samples of bladder cancer patients. Int. J. Cancer Res. 1997, 74, 625-629. [CrossRef]

82. Mourah, S.; Cussenot, O.; Vimont, V.; Desgrandchamps, F.; Teillac, P.; Cochant-Priollet, B.; Le Duc, A.; Fiet, J.; Soliman, H. Assessment of microsatellite instability in urine in the detection of transitional-cell carcinoma of the bladder. Int. J. Cancer Res. 1998, 79, 629-633. [CrossRef]

83. Steiner, G.; Reinschmidt, G.; Müller, S.C. Molecular genetic diagnosis of de novo and recurrent bladder cancer. Electrophoresis 1999, 20, 280-282. [CrossRef]

84. Baron, A.; Mastroeni, F.; Moore, P.S.; Bonetti, F.; Orlandini, S.; Manfrin, E.; Schiavone, D.; Migliorini, F.; Lusuardi, L.; Mobilio, G.; et al. Detection of bladder cancer by semi-automated microsatellite analysis of urine sediment. Adv. Clin. Path. 2000, 4, 19-24.

85. Christensen, M.; Wolf, H.; Orntoft, T.F. Microsatellite alterations in urinary sediments from patients with cystitis and bladder cancer. Int. J. Cancer Res. 2000, 85, 614-617. [CrossRef]

86. Schneider, A.; Borgnat, S.; Lang, H.; Régine, O.; Lindner, V.; Kassem, M.; Saussine, C.; Oudet, P.; Jacqmin, D.; Gaub, M.P. Evaluation of microsatellite analysis in urine sediment for diagnosis of bladder cancer. Cancer Res. 2000, 60, 4617-4622.

87. Zhang, J.; Fan, Z.; Gao, Y.; Xiao, Z.; Li, C.; An, Q.; Cheng, S. Detecting bladder cancer in the Chinese by microsatellite analysis: Ethnic and etiologic considerations. J. Natl. Cancer Inst. 2001, 93, 45-50. [CrossRef]

88. Mao, L.; Lee, D.J.; Tockman, M.S.; Erozan, Y.S.; Askin, F.; Sidransky, D. Microsatellite alterations as clonal markers for the detection of human cancer. Proc. Natl. Acad. Sci. USA 1994, 91, 9871-9875. [CrossRef]

89. Zeger, S.; Liang, K.-Y. An overview of methods for the analysis of longitudinal data. Stat. Med. 1992, 11, 1825-1839. [CrossRef]

90. Bartoletti, R.; Dal Canto, M.; Cai, T.; Piazzini, M.; Travaglini, F.; Gavazzi, A.; Rizzo, M. Early diagnosis and monitoring of superficial transitional cell carcinoma by microsatellite analysis on urine sediment. Oncol. Rep. 2005, 13, 531-537. [CrossRef]

91. Bartoletti, R.; Cai, T.; Dal Canto, M.; Boddi, V.; Nesi, G.; Piazzini, M. Multiplex polymerase chain reaction for microsatellite analysis of urine sediment cells: A rapid and inexpensive method for diagnosing and monitoring superficial transitional bladder cell carcinoma. J. Urol. 2006, 175, 2032-2037. [CrossRef]

92. van Rhijn, B.W.; Lurkin, I.; Chopin, D.K.; Kirkels, W.J.; Thiery, J.P.; van der Kwast, T.H.; Radvanyi, F.; Zwarthoff, E.C. Combined microsatellite and FGFR3 mutation analysis enables a highly sensitive detection of urothelial cell carcinoma in voided urine. Clin. Cancer Res. 2003, 9, 257-263.

93. Vanrhijn, B.; Smit, M.; Vangeenen, D.; Wijnmaalen, A.; Kirkels, W.; Vanderkwast, T.; Kuenenboumeester, V.; Zwarthoff, E. Surveillance with microsatellite analysis of urine in bladder cancer patients treated by radiotherapy. Eur. Urol. 2003, 43, 369-373. [CrossRef]

94. van Rhijn, B.W.G.; van der Poel, H.G.; van der Kwast, T.H. Urine markers for bladder cancer surveillance: A systematic review. Eur. Urol. 2005, 47, 736-748. [CrossRef]

95. van Oers, J.M.M.; Lurkin, I.; van Exsel, A.J.A.; Nijsen, Y.; van Rhijn, B.W.G.; van der Aa, M.N.M.; Zwarthoff, E.C. A simple and fast method for the simultaneous detection of nine fibroblast growth factor receptor 3 mutations in bladder cancer and voided urine. Clin. Cancer Res. 2005, 11, 7743-7748. [CrossRef]

96. van der Poel, H.G.; van Rhijn, B.W.G.; Peelen, P.; Debruyne, F.M.J.; Boon, M.E.; Schalken, J.A. Consecutive quantitative cytology in bladder cancer. Urology 2000, 56, 584-588. [CrossRef]

97. Wallerand, H. Mutations in TP53, but not FGFR3, in urothelial cell carcinoma of the bladder are influenced by smoking: Contribution of exogenous versus endogenous carcinogens. Carcinogenesis 2005, 26, 177-184. [CrossRef]

98. Rieger-Christ, K.M.; Medina, A.; Lee, P.J.; Rieger-Christ, K.M.; Mourtzinos, A.; Lee, P.J.; Libertino, J.A.; Summerhayes, I.C. Identification of fibroblast growth factor receptor 3 mutations in urine sediment DNA samples complements cytology in bladder tumor detection. Cancer 2003, 98, 737-744. [CrossRef]

99. van Rhijn, B.W.G.; Vis, A.N.; van der Kwast, T.H.; Kirkels, W.J.; Radvanyi, F.; Ooms, E.C.M.; Chopin, D.K.; Boevé, E.R.; Jöbsis, A.C.; Zwarthoff, E.C. Molecular grading of urothelial cell carcinoma with fibroblast growth factor receptor 3 and MIB-1 is superior to pathologic grade for the prediction of clinical outcome. J. Clin. Oncol. 2003, 21, 1912-1921. [CrossRef]

100. Hernández, S.; López-Knowles, E.; Lloreta, J.; Kogevinas, M.; Amorós, A.; Tardón, A.; Carrato, A.; Serra, C.; Malats, N.; Real, F.X. Prospective study of FGFR3 mutations as a prognostic factor in nonmuscle invasive urothelial bladder carcinomas. J. Clin. Oncol. 2006, 24, 3664-3671. [CrossRef]

101. Montironi, R. Editorial comment on: FGFR3 mutations and a normal CK20 staining pattern define low-grade noninvasive urothelial bladder tumours. Eur. Urol. 2007, 52, 768. [CrossRef]

102. Burger, M.; van der Aa, M.N.M.; van Oers, J.M.M.; Brinkmann, A.; van der Kwast, T.H.; Steyerberg, E.C.; Stoehr, R.; Kirkels, W.J.; Denzinger, S.; Wild, P.J.; et al. Prediction of progression of non-muscle-invasive bladder cancer by WHO 1973 and 2004 grading and by FGFR3 mutation status: A prospective study. Eur. Urol. 2008, 54, 835-844. [CrossRef] 
103. Knowles, M.A. Role of FGFR3 in urothelial cell carcinoma: Biomarker and potential therapeutic target. World J. Urol. 2007, 25, 581-593. [CrossRef]

104. Song, X.-B.; Zhou, Y.; Ying, B.-W.; Wang, L.-L.; Li, Y.-S.; Liu, J.-F.; Bai, X.-G.; Zhang, L.; Lu, X.-J.; Wang, J.; et al. Short-tandem repeat analysis in seven Chinese regional populations. Genet. Mol. Biol. 2010, 33, 605-609. [CrossRef] [PubMed]

105. Cai, G.Q.; Chen, L.X.; Tong, D.Y.; Ou, J.H.; Wu, X.Y. Mutations of 15 short tandem repeat loci in Chinese population. Zhonghua Yi Xue Yi Chuan Xue Za Zhi 2005, 22, 507-509. [PubMed]

106. Chakraborty, R.; Smouse, P.E.; Neel, J.V. Population amalgamation and genetic variation: Observations on artificially agglomerated tribal populations of Central and South America. Am. J. Hum. Genet. 1988, 43, 709-725. [PubMed]

107. Chu, J.Y.; Huang, W.; Kuang, S.Q.; Wang, J.M.; Xu, J.J.; Chu, Z.T.; Yang, Z.Q.; Lin, K.Q.; Li, P.; Wu, M.; et al. Genetic relationship of populations in China. Proc. Natl. Acad. Sci. USA 1998, 95, 11763-11768. [CrossRef]

108. Deng, Y.-J.; Yan, J.-W.; Yu, X.-G.; Li, Y.-Z.; Mu, H.-F.; Huang, Y.-Q.; Shi, X.-T.; Sun, W.-M. Genetic analysis of 15 STR loci in Chinese Han population from West China. Genomics Proteomics Bioinform. 2007, 5, 66-69. [CrossRef]

109. Edwards, A.; Hammond, H.A.; Jin, L.; Caskey, C.T.; Chakraborty, R. Genetic variation at five trimeric and tetrameric tandem repeat loci in four human population groups. Genomics 1992, 12, 241-253. [CrossRef]

110. Grunbaum, B.W.; Selvin, S.; Pace, N.; Black, D.M. Frequency distribution and discrimination probability of twelve protein genetic variants in human blood as functions of race, sex, and age. J. Forensic Sci. 1978, 23, 577-587. [CrossRef] [PubMed]

111. Liu, Y.; Liu, Y.; Guo, J.; Fu, X.; Wang, Z.; Liu, Y.; Cai, J.; Zha, L. Genetic polymorphism of 29 STR loci in the Hunan Han population from China. Forensic Sci. Res. 2017, 4, 351-353. [CrossRef]

112. Hyun, J.S.; Jo, B.-K.; Park, C.J.; Yi, J.Y.; Lee, J.Y.; Rhyu, M.-G. Loss of heterozygosity and PCR artifacts in a microsatellite analysis of psoriasis and colorectal cancer. J. Korean Med. Sci. 2002, 17, 641-647. [CrossRef]

113. Sieben, N.L.G.; ter Haar, N.T.; Cornelisse, C.J.; Fleuren, G.J.; Cleton-Jansen, A.-M. PCR artifacts in LOH and MSI analysis of microdissected tumor cells. Hum. Pathol. 2000, 31, 1414-1419. [CrossRef]

114. Bocker, T.; Diermann, J.; Friedl, W.; Gebert, J.; Holinski-Feder, E.; Karner-Hanusch, J.; von Knebel-Doeberitz, M.; Koelble, K.; Moeslein, G.; Schackert, H.K.; et al. Microsatellite instability analysis: A multicenter study for reliability and quality control. Cancer Res. 1997, 57, 4739-4743.

115. Cawkwell, L.; Li, D.; Lewis, F.A.; Martin, I.; Dixon, M.F.; Quirke, P. Microsatellite instability in colorectal cancer: Improved assessment using fluorescent polymerase chain reaction. Gastroenterology 1995, 109, 465-471. [CrossRef]

116. Canzian, F.; Salovaara, R.; Hemminki, A.; Kristo, P.; Chadwick, R.B.; Aaltonen, L.A.; de la Chapelle, A. Semiautomated assessment of loss of heterozygosity and replication error in tumors. Cancer Res. 1996, 56, 3331-3337.

117. Suraweera, N.; Duval, A.; Reperant, M.; Vaury, C.; Furlan, D.; Leroy, K.; Seruca, R.; Iacopetta, B.; Hamelin, R. Evaluation of tumor microsatellite instability using five quasimonomorphic mononucleotide repeats and pentaplex PCR. Gastroenterology 2002, 123, 1804-1811. [CrossRef]

118. Goel, A.; Nagasaka, T.; Hamelin, R.; Boland, C.R. An optimized pentaplex PCR for detecting DNA mismatch repair-deficient colorectal cancers. PLoS ONE 2010, 5, e9393. [CrossRef]

119. Takehara, Y.; Nagasaka, T.; Nyuya, A.; Haruma, T.; Haraga, J.; Mori, Y.; Nakamura, K.; Fujiwara, T.; Boland, C.R.; Goel, A. Accuracy of four mononucleotide-repeat markers for the identification of DNA mismatch-repair deficiency in solid tumors. $J$. Transl. Med. 2018, 16, 5. [CrossRef] [PubMed]

120. Laghi, L.; Bianchi, P.; Malesci, A. Differences and evolution of the methods for the assessment of microsatellite instability. Oncogene 2008, 27, 6313-6321. [CrossRef]

121. Dal Canto, M.; Bartoletti, R.; Travaglini, F.; Piazzini, M.; Lodovichi, G.; Rizzo, M.; Selli, C. Molecular urinary sediment analysis in patients with transitional cell bladder carcinoma. Anticancer Res. 2003, 23, 5095-5100. [PubMed]

122. Choi, C.; Kim, M.H.; Juhng, S.-W.; Oh, B.-R. Loss of heterozygosity at chromosome segments 8p22 and 8p11.2-21.1 in transitionalcell carcinoma of the urinary bladder. Int. J. Cancer Res. 2000, 86, 501-505. [CrossRef]

123. van Tilborg, A.A.G.; de Vries, A.; de Bont, M.; Groenfeld, L.E.; Zwarthoff, E.C. The random development of LOH on chromosome 9q in superficial bladder cancers. J. Pathol. 2002, 198, 352-358. [CrossRef] [PubMed]

124. Knowles, M.A. Identification of novel bladder tumour suppressor genes. Electrophoresis 1999, 20, 269-279. [CrossRef] 